\title{
LEVEL II SCOUR ANALYSIS FOR BRIDGE 32 (FERRTH00190032) on TOWN HIGHWAY 19, crossing the SOUTH SLANG LITTLE OTTER CREEK, FERRISBURGH, VERMONT
}

Open-File Report 98-025

Prepared in cooperation with

VERMONT AGENCY OF TRANSPORTATION

and

FEDERAL HIGHWAY ADMINISTRATION

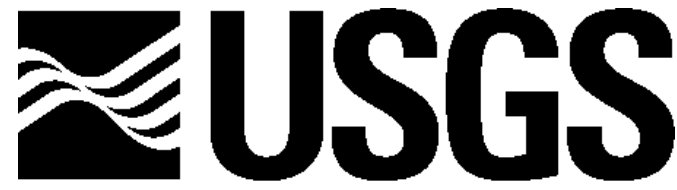

science for a changing world

U.S. Department of the Interior

U.S. Geological Survey 


\section{LEVEL II SCOUR ANALYSIS FOR BRIDGE 32 (FERRTH00190032) on TOWN HIGHWAY 19, crossing the SOUTH SLANG LITTLE OTTER CREEK, FERRISBURGH, VERMONT \\ By MICHAEL A. IVANOFF AND EMILY C. WILD}

U.S. Geological Survey Open-File Report 98-025

Prepared in cooperation with

VERMONT AGENCY OF TRANSPORTATION

and

FEDERAL HIGHWAY ADMINISTRATION 


\title{
U.S. DEPARTMENT OF THE INTERIOR BRUCE BABBITT, Secretary
}

\author{
U.S. GEOLOGICAL SURVEY \\ Tom Casadevall, Acting Director
}

For additional information write to:

District Chief

U.S. Geological Survey 361 Commerce Way

Pembroke, NH 03275-3718
Copies of this report may be purchased from:

U.S. Geological Survey

Branch of Information Services

Open-File Reports Unit

Box 25286

Denver, CO 80225-0286 


\section{CONTENTS}

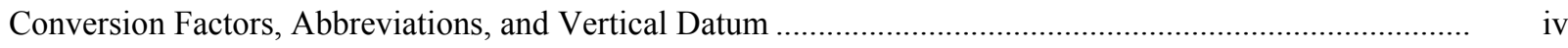

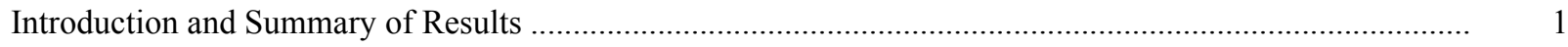

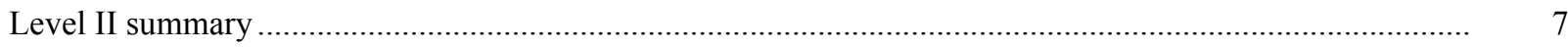

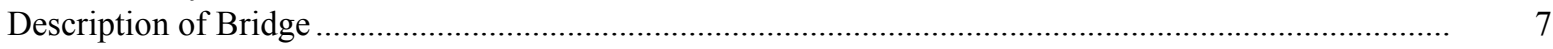

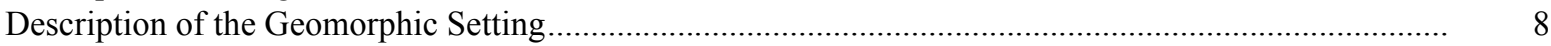

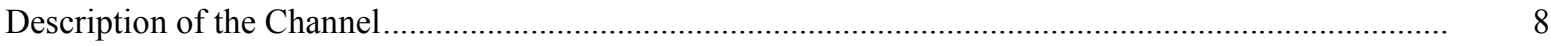

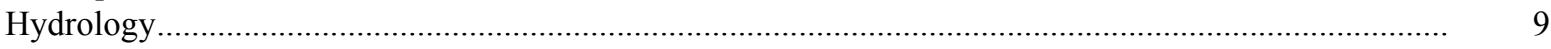

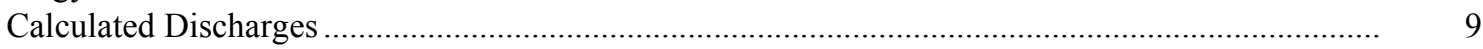

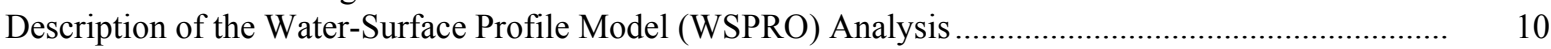

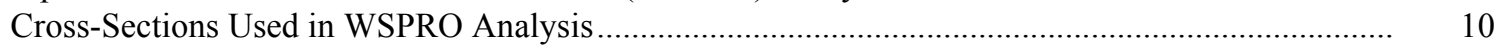

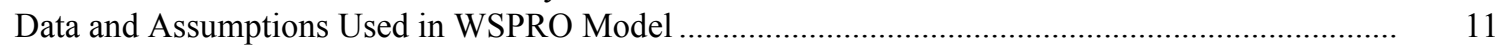

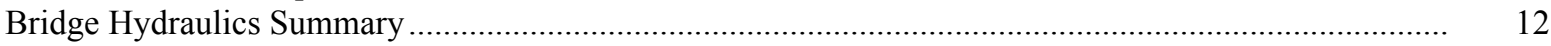

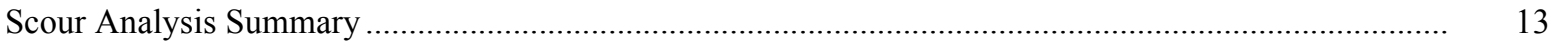

Special Conditions or Assumptions Made in Scour Analysis ..................................................... 13

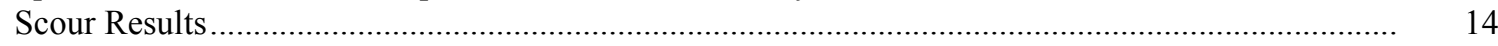

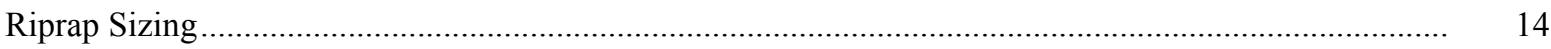

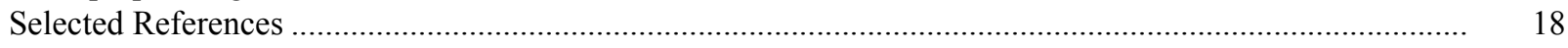

Appendices:

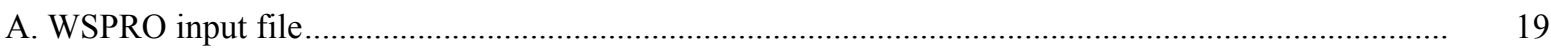

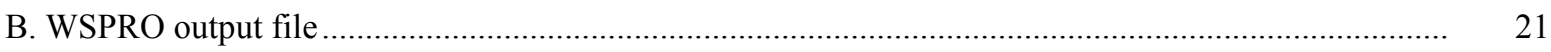

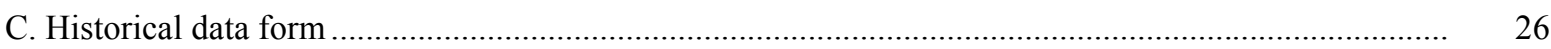

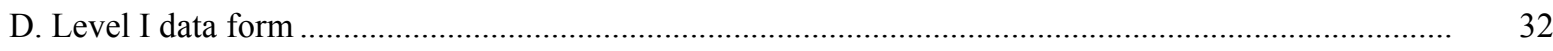

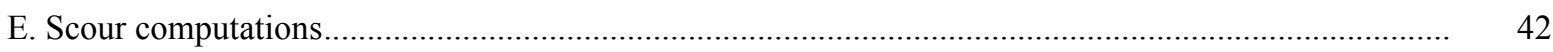

\section{FIGURES}

1. Map showing location of study area on USGS $1: 25,000$ scale map ................................................ 3

2. Map showing location of study area on Vermont Agency of Transportation town highway map ......

3. Structure FERRTH00190032 viewed from upstream (July 2, 1996)

4. Downstream channel viewed from structure FERRTH00190032 (July 2, 1996)

5. Upstream channel viewed from structure FERRTH00190032 (July 2, 1996)

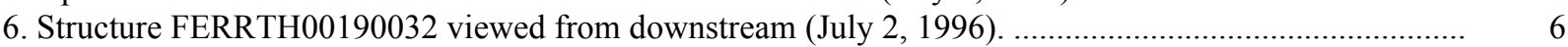

7. Water-surface profiles for the 100- and 500-year discharges at structure

FERRTH00190032 on Town Highway 19, crossing the South Slang Little Otter Creek,

Ferrisburg, Vermont.

5

6
6

8. Scour elevations for the 100 - and 500-year discharges at structure

FERRTH00190032 on Town Highway 19, crossing the South Slang Little Otter Creek,

Ferrisburg, Vermont.

\section{TABLES}

1. Remaining footing/pile depth at abutments for the 100-year discharge at structure

FERRTH00190032 on Town Highway 19, crossing the South Slang Little Otter Creek,

Ferrisburg, Vermont.

2. Remaining footing/pile depth at abutments for the 500-year discharge at structure

FERRTH00190032 on Town Highway 19, crossing the South Slang Little Otter Creek,

Ferrisburg, Vermont. 


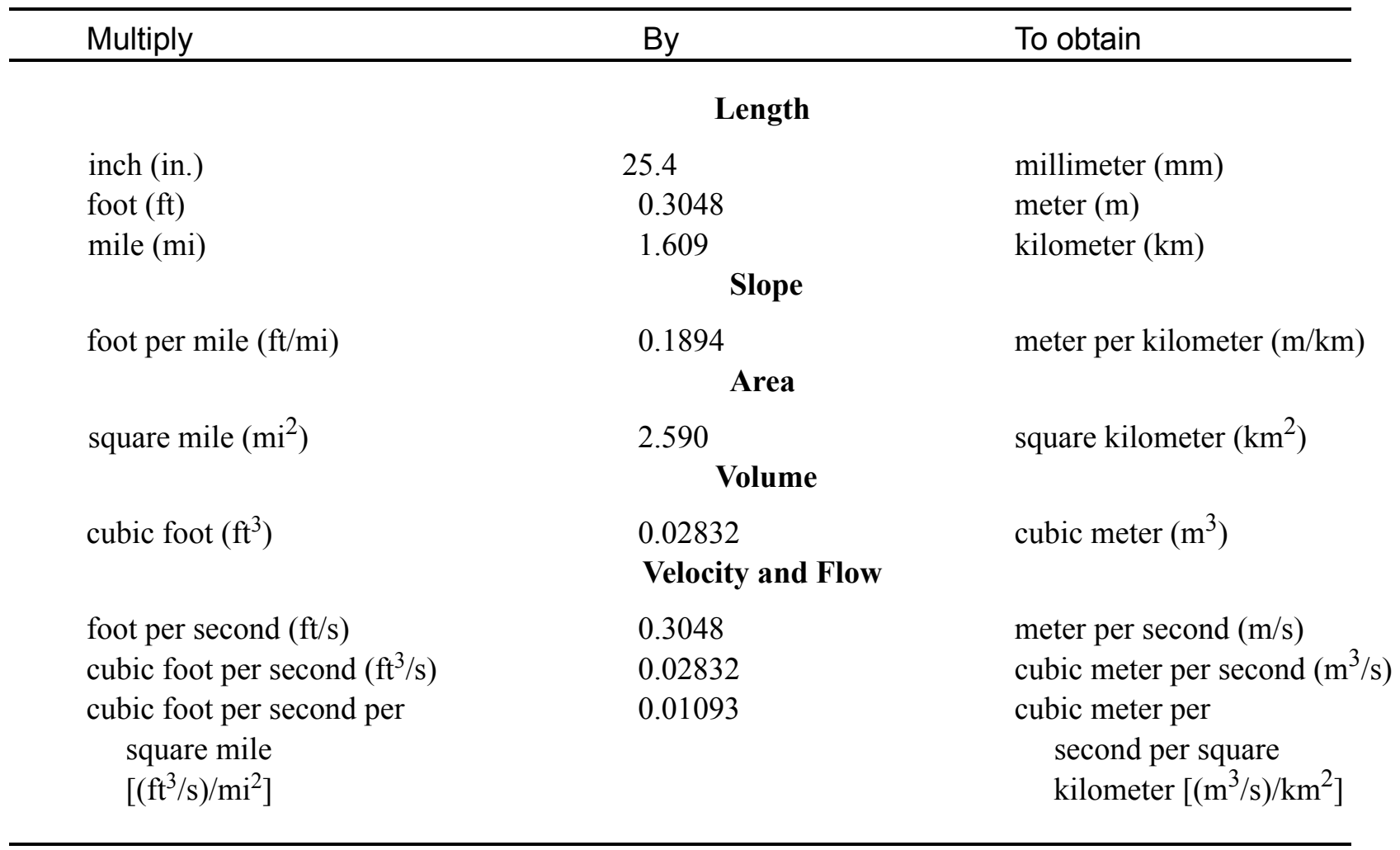

\section{OTHER ABBREVIATIONS}

$\begin{array}{lrlr}\text { BF } & \text { bank full } & \text { LWW } & \text { left wingwall } \\ \text { cfs } & \text { cubic feet per second } & \text { Max } & \text { maximum } \\ \mathrm{D}_{50} & \text { median diameter of bed material } & \text { MC } & \text { main channel } \\ \mathrm{DS} & \text { downstream } & \text { RAB } & \text { right abutment } \\ \text { elev. } & \text { elevation } & \text { RABUT } & \text { flood plain } \\ \mathrm{f} / \mathrm{p} & \text { RB } & \text { race of right abutment } \\ \mathrm{ft}^{2} & \text { square feet } & \text { ROB } & \text { right bank } \\ \mathrm{ft} / \mathrm{ft} & \text { feet per foot } & \text { RWW } & \text { right overbank } \\ \text { FEMA } & \text { Federal Emergency Management Agency } & \text { TH } & \text { town highway } \\ \text { FHWA } & \text { Federal Highway Administration } & \text { UB } & \text { under bridge } \\ \text { JCT } & \text { junction } & \text { US } & \text { upstream } \\ \text { LAB } & \text { left abutment } & \text { USGS } & \text { United States Geological Survey } \\ \text { LABUT } & \text { face of left abutment } & \text { VTAOT } & \text { Vermont Agency of Transportation } \\ \text { LB } & \text { left bank } & \text { WSPRO } & \text { water-surface profile model } \\ \text { LOB } & \text { left overbank } & \text { yr } & \text { year }\end{array}$

In this report, the words "right" and "left" refer to directions that would be reported by an observer facing downstream. Sea level: In this report, "sea level” refers to the National Geodetic Vertical Datum of 1929-- a geodetic datum derived from a general adjustment of the first-order level nets of the United States and Canada, formerly called Sea Level Datum of 1929.

In the appendices, the above abbreviations may be combined. For example, USLB would represent upstream left bank. 


\title{
LEVEL II SCOUR ANALYSIS FOR BRIDGE 32 (FERRTH00190032) ON TOWN HIGHWAY 19, CROSSING THE SOUTH SLANG LITTLE OTTER CREEK, FERRISBURGH, VERMONT
}

\author{
By Michael A. Ivanoff and Emily C. Wild
}

\section{INTRODUCTION AND SUMMARY OF RESULTS}

This report provides the results of a detailed Level II analysis of scour potential at structure FERRTH00190032 on Town Highway 19 crossing the South Slang Little Otter Creek (Hawkins Slang Brook), Ferrisburg, Vermont (figures 1-8). A Level II study is a basic engineering analysis of the site, including a quantitative analysis of stream stability and scour (FHWA, 1993). Results of a Level I scour investigation also are included in appendix $\mathrm{E}$ of this report. A Level I investigation provides a qualitative geomorphic characterization of the study site. Information on the bridge, gleaned from Vermont Agency of Transportation (VTAOT) files, was compiled prior to conducting Level I and Level II analyses and is found in appendix D.

The site is in the Champlain section of the St. Lawrence Valley physiographic province in west-central Vermont. The $8.00-\mathrm{mi}^{2}$ drainage area is in a predominantly rural and forested basin. In the vicinity of the study site, the surface cover consists of wetlands upstream and downstream of the bridge with trees and pasture on the wide flood plains.

In the study area, the South Slang Little Otter Creek has a meandering channel with essentially no channel slope, an average channel top width of $932 \mathrm{ft}$ and an average bank height of $6 \mathrm{ft}$. The channel bed material ranges from clay to sand. Sieve analysis indicates that greater than $50 \%$ of the sample is coarse silt and clay and thus a medium grain size by use of sieve analysis was indeterminate. The median grain size was assumed to be a course silt with a size (D50) of $0.061 \mathrm{~mm}(0.0002 \mathrm{ft})$. The geomorphic assessment at the time of the Level I and Level II site visit on July 2, 1996, indicated that the reach was stable.

The Town Highway 19 crossing of the South Slang Little Otter Creek is a 45-ft-long, twolane bridge consisting of one 42-foot concrete box-beam span (Vermont Agency of Transportation, written communication, December 11, 1995). The opening length of the structure parallel to the bridge face is $41.8 \mathrm{ft}$. The bridge is supported by vertical, concrete abutments. The channel is skewed approximately 5 degrees to the opening while the opening-skew-to-roadway is zero degrees. 
A scour hole $3.5 \mathrm{ft}$ deeper than the mean thalweg depth was observed in the upstream channel. Also a scour hole $2.0 \mathrm{ft}$ deeper than the mean thalweg depth was observed along the right abutment during the Level I assessment. The scour protection measures at the site are type-1 stone fill (less than 12 inches diameter) around the left and right abutments, along the upstream and downstream road embankments, and across the entire upstream and downstream bridge face. Additional details describing conditions at the site are included in the Level II Summary and appendices D and E.

Scour depths and recommended rock rip-rap sizes were computed using the general guidelines described in Hydraulic Engineering Circular 18 (Richardson and others, 1995) for the 100- and 500-year discharges. Total scour at a highway crossing is comprised of three components: 1) long-term streambed degradation; 2) contraction scour (due to accelerated flow caused by a reduction in flow area at a bridge) and; 3 ) local scour (caused by accelerated flow around piers and abutments). Total scour is the sum of the three components. Equations are available to compute depths for contraction and local scour and a summary of the results of these computations follows.

Contraction scour for all modelled flows ranged from 14.0 to $20.2 \mathrm{ft}$. The worst-case contraction scour occurred at the 500-year discharge. Abutment scour ranged from 3.2 to $8.3 \mathrm{ft}$. The worst-case abutment scour occurred at the 500-year discharge. The predicted scour is well above the pile bottom elevations. Additional information on scour depths and depths to armoring are included in the section titled "Scour Results". Scoured-streambed elevations, based on the calculated scour depths, are presented in tables 1 and 2. A crosssection of the scour computed at the bridge is presented in figure 8. Scour depths were calculated assuming an infinite depth of erosive material and a homogeneous particle-size distribution.

Computed scour depths are evaluated in combination with other information including (but not limited to) historical performance during flood events, the geomorphic stability assessment, existing scour protection measures, and the results of the hydraulic analyses. Therefore, scour depths adopted by VTAOT may differ from the computed values documented herein. 


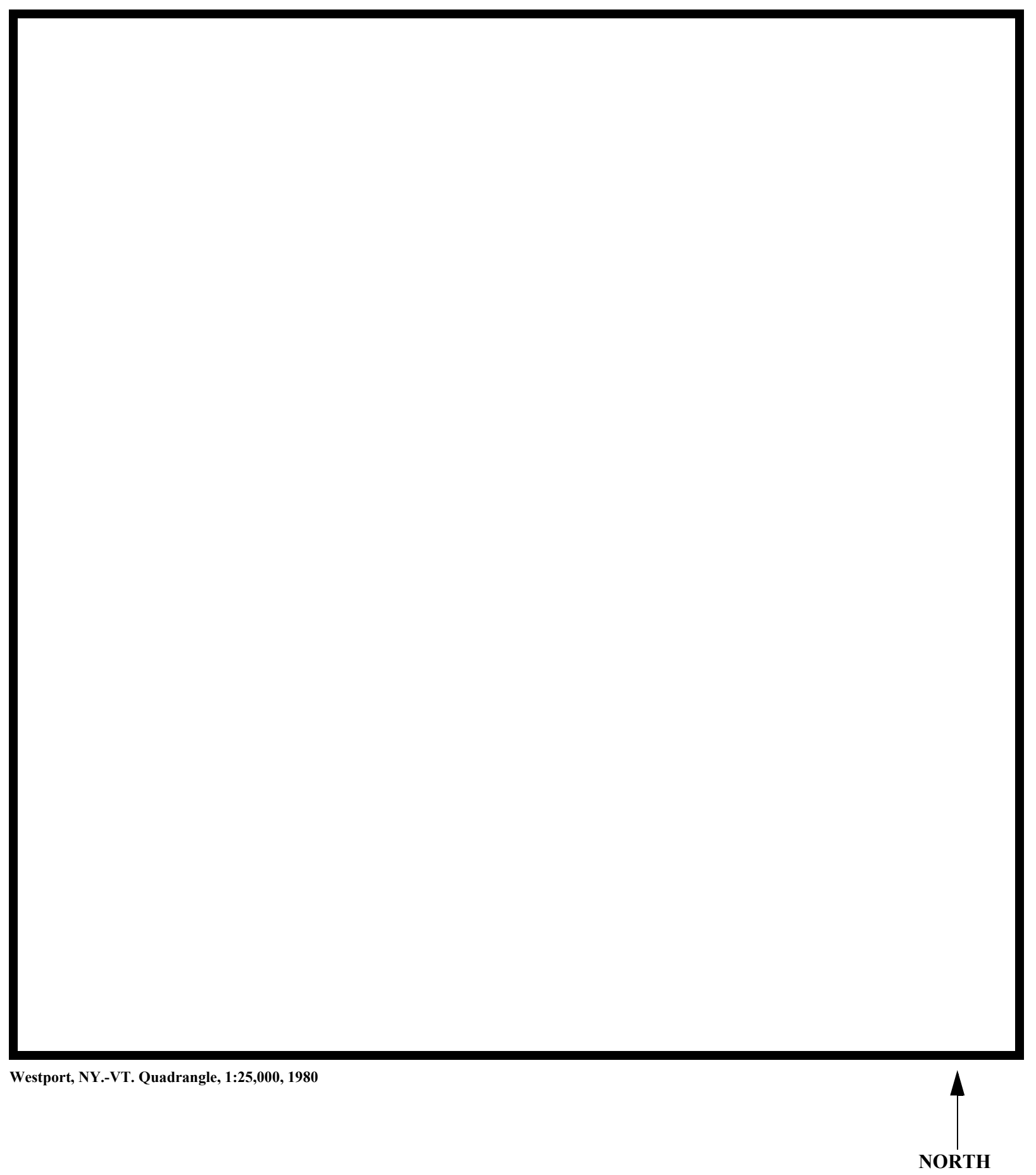

Figure 1. Location of study area on USGS 1:25,000 scale map. 
Figure 2. Location of study area on Vermont Agency of Transportation town highway map. 

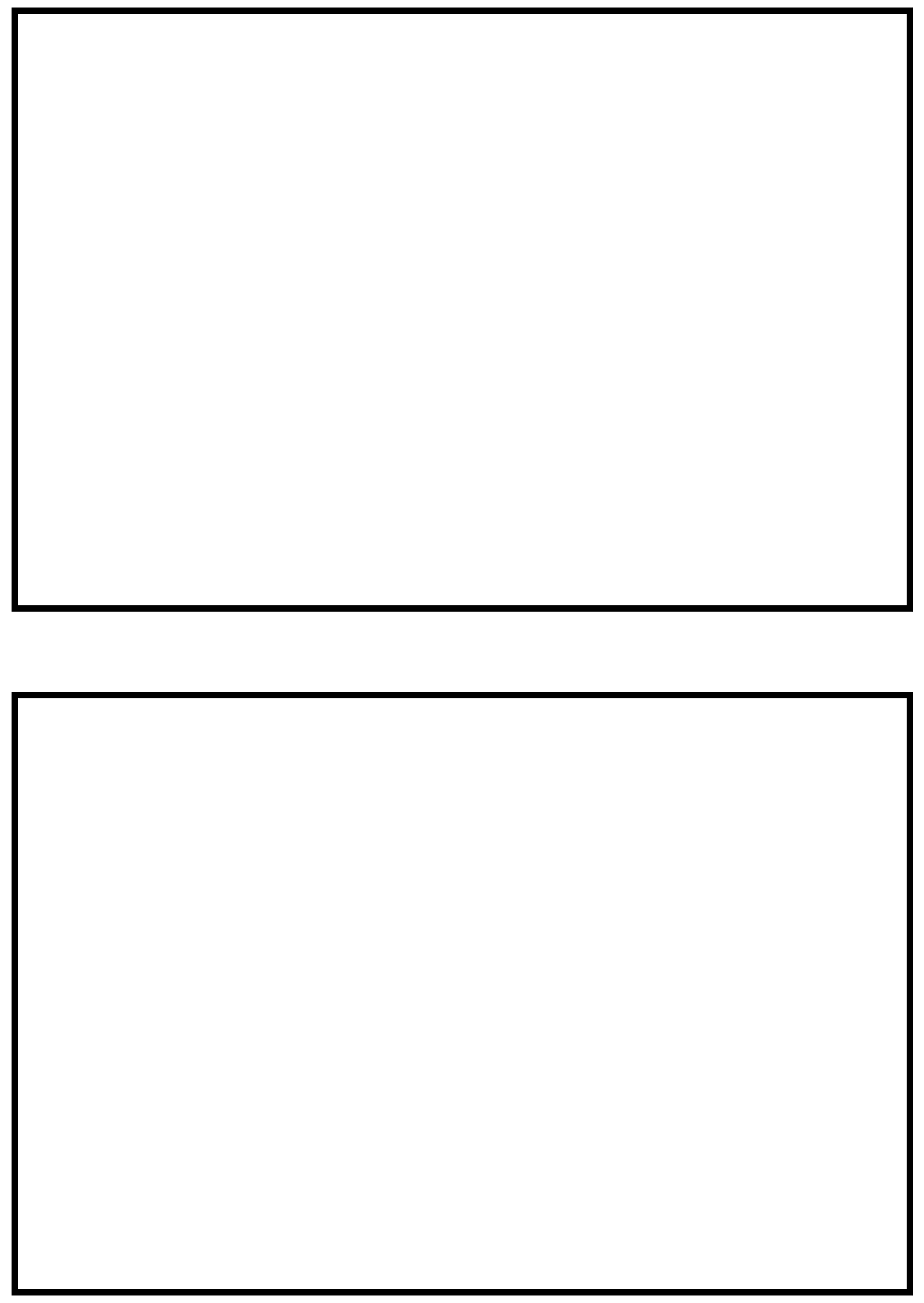

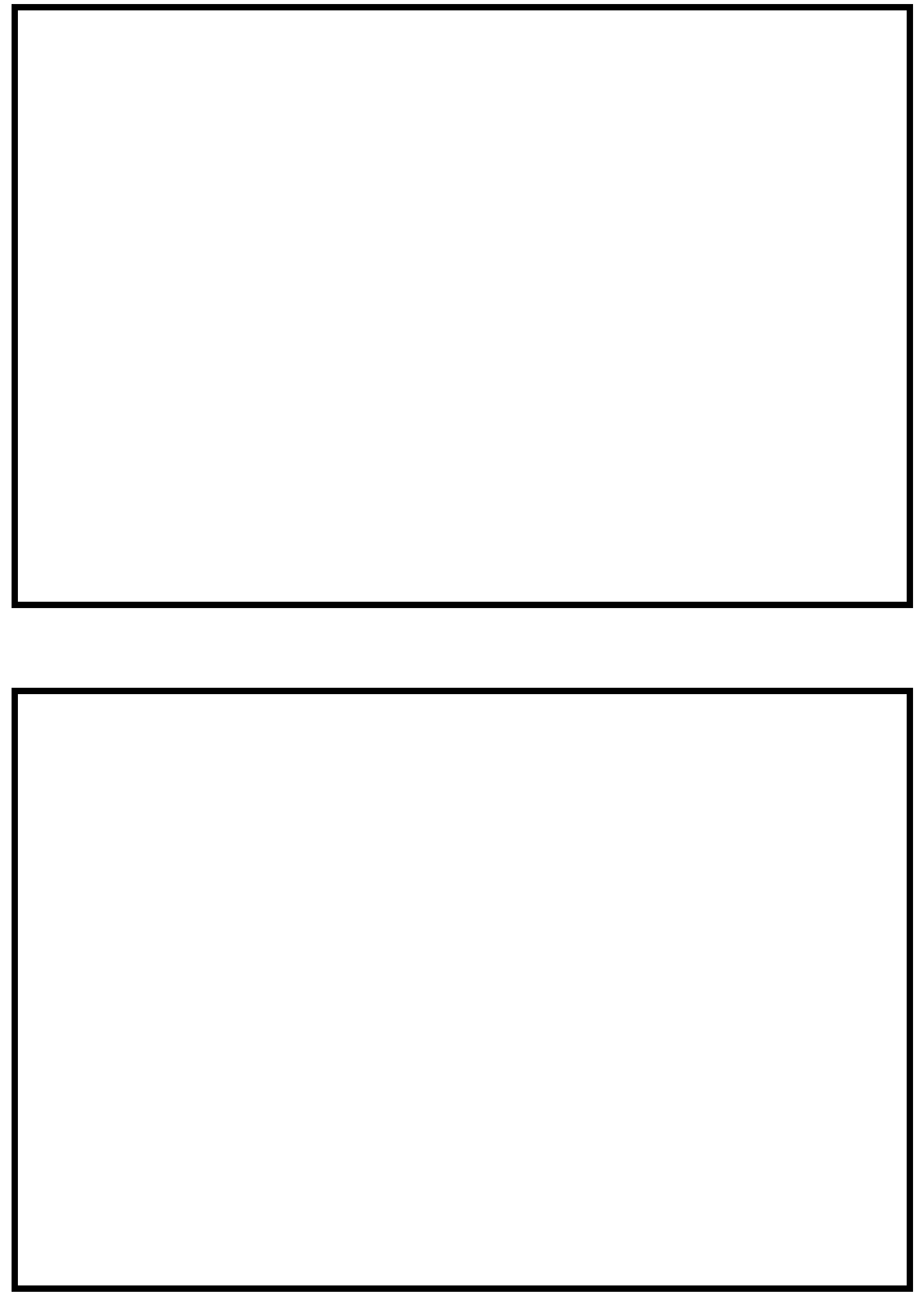


\section{LEVEL II SUMMARY}

\begin{tabular}{llllll} 
& Structure Number & FERRTH00190032 & Stream & \multicolumn{3}{c}{ South Slang Little Otter Creek } \\
& Road & TH 19 & District & 5
\end{tabular}

\section{Description of Bridge}

Bridge length $\stackrel{45.0}{ } \boldsymbol{f t} \quad$ Bridge width $\stackrel{24.8}{f} \quad$ Max span length $\stackrel{42.0}{f t}$ Alignment of bridge to road (on curve or straight)

Abutment type Vertical, concrete

Stone fill on abutment? Yes

\section{Embankment type} Straight

Drto af insnortion Type-1, around the left and right abutments and across the upstream and downstream bridge faces.

hole in front of the right abutment exposing the footing.

\section{Yes} $\underline{5}$

\section{Is bridge skewed to flood flow according to No ' survey? Angle}

The channel meanders through a wetland in the upstream reach. A scour hole has deyeloped upstream of the bridge and through the constriction.

Debris accumulation on bridge at time of Level I or Level II site visit:

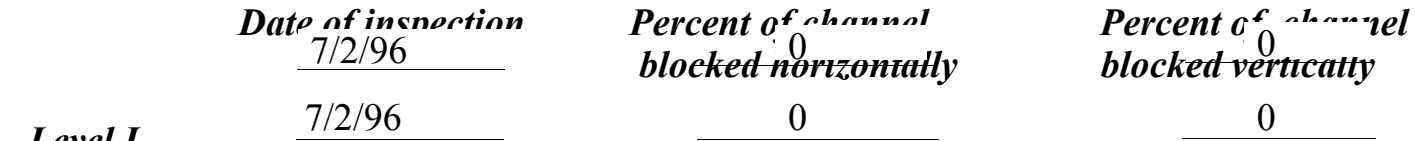

Level II

Moderate. There is some debris caught on the upstream and downstream road embankments.

Potential for debris

None as of 7/2/96.

Doscriho anv fonturos noar ar at tho hridoo that mav, affort flow, (includo ahsorvation dato) 


\section{Description of the Geomorphic Setting}

General topography The channel is located within a wide low relief valley with flat to slightly irregular, wide flood plain.

Geomorphic conditions at bridge site: downstream (DS), upstream (US)

Date of inspection $\quad 7 / 2 / 96$

DS left: $\quad$ Wide flood plain.

DS right: $\quad$ Slightly sloped channel bank to a wide flood plain.

US left: $\quad$ Slightly sloped channel bank to a wide flood plain.

US right: $\quad$ Slightly sloped channel bank to a wide flood plain.

\section{Description of the Channel}

\begin{tabular}{|c|c|c|c|c|}
\hline \multirow[b]{2}{*}{ Average top width } & 932 & \multirow[b]{2}{*}{ Average depth } & 6 & \multirow[b]{2}{*}{$f+$} \\
\hline & Silt / Sand & & Silt / Sand & \\
\hline Predominant bed me & & Bank material & Ieandering bc & \\
\hline
\end{tabular}

stable with alluvial channel boundaries and a wide flood plain.

Vegetative co 1 Trees and brush with pasture on the flood plain.

DS left: $\quad$ Trees and brush with pasture on the flood plain.

DS right: $\quad$ Trees and brush with pasture on the flood plain.

US left: $\quad$ Trees and brush with pasture on the flood plain.

US right: $\quad$ Yes

Do banks appear stable? -

y mus, ме

date of observatton.

None 7/2/96.

Describe any obstructions in channel and date of observation. 


\title{
Hydrology
}

Drainage area $\stackrel{8.00}{\mathrm{mi}^{2}}$

Percentage of drainage area in physiographic provinces: (approximate)

Physiographic province/section

St. Lawrence Valley / Champlain
Percent of drainage area 100

\begin{abstract}
Is drainage area considered rural or urban?
Rural None.

urbanization:
\end{abstract}

Is there a USGS gage on the stream of interest?

No

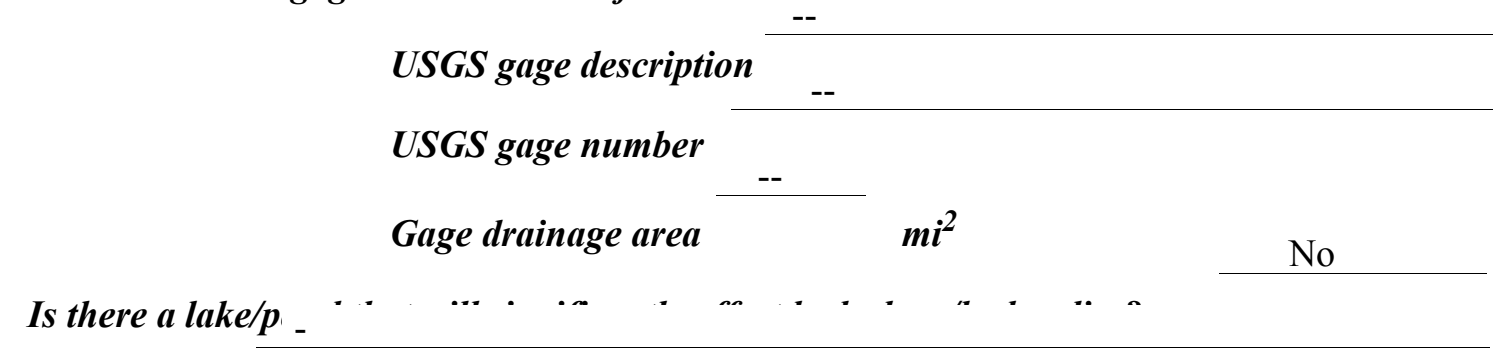

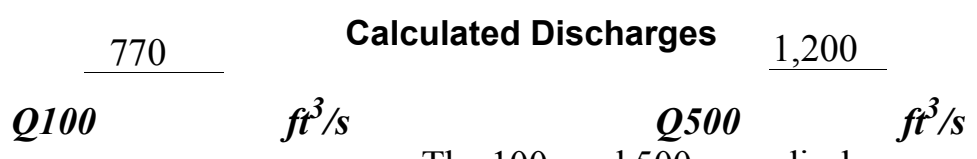

The 100- and 500-year discharges are based on the

empirical method documented in "Factors Influencing the Occurrence of Floods in a Humid Region of Diverse Terrain: U.S. Geological Survey Water-Supply Paper 1580-B” (Benson, 1962). The Benson results were chosen due to their central tendency among the results from several empirical flood frequency curves (Benson, 1962; Johnson and Tasker, 1974; FHWA, 1983; Potter, 1957a\&b; Talbot, 1887). 


\section{Description of the Water-Surface Profile Model (WSPRO) Analysis}

Datum for WSPRO analysis (USGS survey, sea level, VTAOT plans) ～USGS survey

Datum tie between USGS survey and VTAOT plans $\quad$ Subtract $400.3 \mathrm{ft}$ from the USGS

arbitrary survey datum to obtain the datum used in the VTAOT plans.

Description of reference marks used to determine USGS datum. $\quad$ RM1 is a VT Highway

Dept. brass tablet on top of the downstream end of the right abutment (elev. $500.52 \mathrm{ft}$, arbitrary

survey datum). RM2 is a chiseled $\mathrm{X}$ on top of the upstream end of the left abutment (elev.

$500.09 \mathrm{ft}$, arbitrary survey datum).

\section{Cross-Sections Used in WSPRO Analysis}

\begin{tabular}{|c|c|c|c|}
\hline${ }^{1}$ Cross-section & $\begin{array}{c}\text { Section } \\
\text { Reference } \\
\text { Distance } \\
\text { (SRD) in feet }\end{array}$ & $\begin{array}{c}{ }^{2} \text { Cross-section } \\
\text { development }\end{array}$ & Comments \\
\hline EXITX & -59 & 1 & Exit section \\
\hline FULLV & 0 & 2 & $\begin{array}{l}\text { Downstream Full-valley } \\
\text { section (Templated from } \\
\text { EXITX) }\end{array}$ \\
\hline BRIDG & 0 & 1 & Bridge section \\
\hline RDWAY & 15 & 1 & Road Grade section \\
\hline APPRO & 72 & 1 & Approach section \\
\hline
\end{tabular}

${ }^{1}$ For location of cross-sections see plan-view sketch included with Level I field form, Appendix E. For more detail on how cross-sections were developed see WSPRO input file. 


\section{Data and Assumptions Used in WSPRO Model}

Hydraulic analyses of the reach were done by use of the Federal Highway Administration's WSPRO step-backwater computer program (Shearman and others, 1986, and Shearman, 1990). The analyses reported herein reflect conditions existing at the site at the time of the study. Furthermore, in the development of the model it was necessary to assume no accumulation of debris or ice at the site. Results of the hydraulic model are presented in the Bridge Hydraulic Summary, appendix B, and figure 7.

Channel roughness factors (Manning's “ $n$ ”) used in the hydraulic model were estimated using field inspections at each cross section following the general guidelines described by Arcement and Schneider (1989). Final adjustments to the values were made during the modelling of the reach. Channel " $n$ " values for the reach ranged from 0.030 to 0.040 , and overbank " $n$ " values ranged from 0.058 to 0.069 .

The starting water surface was the minimum stage of Lake Champlain during the period of record for the gage (04294500) at Burlington, VT. The flow at all stages is influenced by backwater from Lake Champlain. This starting water surface was assumed for all analysis in order to obtain the maximum scour estimate, as recommended by Richardson and Davis, 1995, p. 26.

The approach section (APPRO) was surveyed one bridge length upstream of the upstream face as recommended by Shearman and others (1986). This location provides a consistent method for determining scour variables. 


\section{Bridge Hydraulics Summary}

$\begin{array}{llll}\text { Average bridge embankment elevation } & 501.4 \\ \text { Average low steel elevation } & 498.1 & \boldsymbol{f t}\end{array}$

100-year discharge $\quad 770 \quad \mathrm{ft}^{3} / \mathrm{s}$

Water-surface elevation in bridge opening $\quad 493.8 \quad f t$

Road overtopping? ___ No Discharge over road ___-- $\mathrm{ft}^{3} / \mathrm{s}$

Area of flow in bridge opening $\quad 91 \quad \mathrm{ft}^{2}$

Average velocity in bridge opening $\quad 8.4 \quad \mathrm{ft} / \mathrm{s}$

Maximum WSPRO tube velocity at bridge $\quad 10.5 \mathrm{ft} / \mathrm{s}$

Water-surface elevation at Approach section with bridge

Water-surface elevation at Approach section without bridge

495.3

Amount of backwater caused by bridge

$2.3 \quad i$

500-year discharge $\quad 1,200 \quad f^{3} / s$

Water-surface elevation in bridge opening

$494.6 f t$

Road overtopping? ___ No Discharge over road

$-f^{3} / \mathrm{s}$

Area of flow in bridge opening

Average velocity in bridge opening 123 $\mathrm{ft}^{2}$

Maximum WSPRO tube velocity at bridge

9.7

$f t / s$

11.8

Water-surface elevation at Approach section with bridge

Water-surface elevation at Approach section without bridge

496.6

Amount of backwater caused by bridge 2.2 , $t$

Incipient overtopping discharge ___ -- $\mathrm{ft}^{3} / \mathrm{s}$

Water-surface elevation in bridge opening $\quad--\quad t$

Area of flow in bridge opening _ $\quad--\quad \mathrm{ft}^{2}$

Average velocity in bridge opening $\quad--\quad f t / s$

Maximum WSPRO tube velocity at bridge _-- $f t / s$

Water-surface elevation at Approach section with bridge

Water-surface elevation at Approach section without bridge

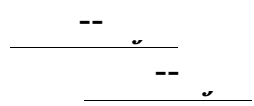

Amount of backwater caused by bridge _ - - it 


\section{Scour Analysis Summary}

\section{Special Conditions or Assumptions Made in Scour Analysis}

Scour depths were computed using the general guidelines described in Hydraulic Engineering Circular 18 (Richardson and Davis, 1995). Scour depths were calculated assuming an infinite depth of erosive material and a homogeneous particle-size distribution. The results of the 100-year and 500-year discharges scour analysis are presented in tables 1 and 2 and the scour depths are presented graphically in figure 8 .

The channel bed material ranges from clay to sand. Sieve analysis indicates that greater than $50 \%$ of the sample is coarse silt and clay and thus a medium grain size by use of sieve analysis was indeterminate. The median grain size was assumed to be a course silt with a size (D50) of $0.061 \mathrm{~mm}(0.0002 \mathrm{ft})$. The coarse silt bed material size was determined from the Sediment Grade Scale in Hydraulic Engineering Circular 20 (Table 1, Lagasse and others, 1995).

Contraction scour for the 100-year and 500-year discharges was computed by use of the Laursen clear-water contraction scour equation (Richardson and Davis, 1995, p. 32, equation 20). The stone fill placed at the upstream and downstream bridge faces may offer some protection of the bed material. The bottom of footing elevation is at $488.3 \mathrm{ft}$ with piles extending $70 \mathrm{ft}$ below the footing to an elevation of $418 \mathrm{ft}$. Calculated scour depths are below the bottom of footing but above the pile depth indicated on the VTAOT plans.

Abutment scour was computed by use of the HIRE equation (Richardson and Davis, 1995, p. 49, equation 29) because the HIRE equation is recommended when the length to depth ratio of the embankment blocking flow exceeds 25 . The variables used by the HIRE abutment-scour equation include the Froude number of the flow approaching the embankments, the length of the embankment blocking flow, and the depth of flow approaching the embankment less any roadway overtopping. 


\section{Scour Results}

100-yr discharge 500-yrdischarge

Incipient

Contraction scour:

(Scour depths in feet)

Main channel

Live-bed scour
Clear-water scour
Depth to armoring
bank
erbank

Right overbank

Local scour:

Abutment scour

Left abutment

3.2

5.6

6.6-

8.3-

\section{Right abutment}

Pier scour

Pier 1

Pier 2

Pier 3

Abutments:

Left abutment

Right abutment

Piers:

Pier 1

Pier 2

\section{Riprap Sizing}

overtopping

discharge

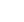




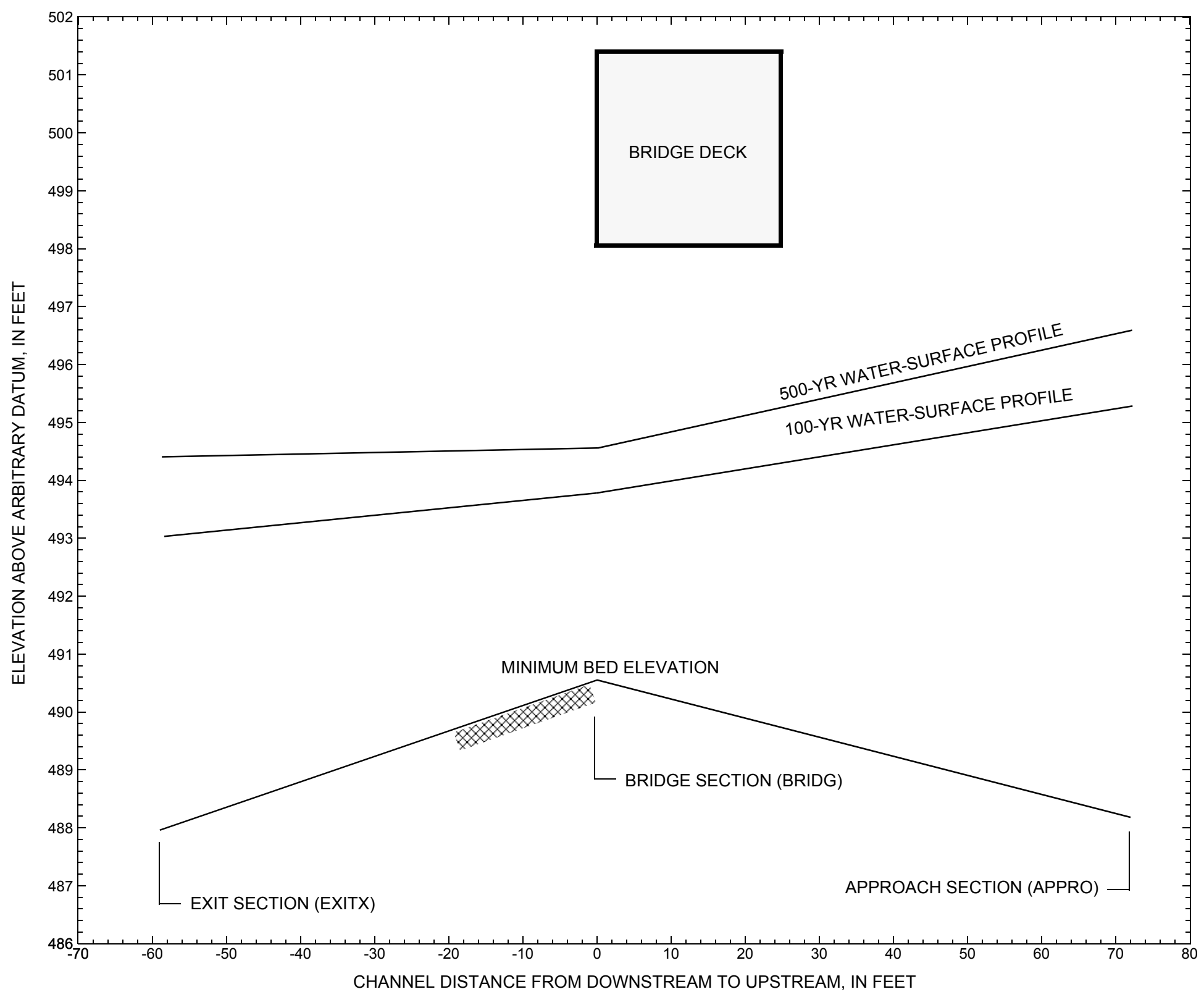

Figure 7. Water-surface profiles for the 100- and 500-yr discharges at structure FERRTH00190032 on Town Highway 19, crossing the South Slang Little Otter Creek, Ferrisburg, Vermont. 


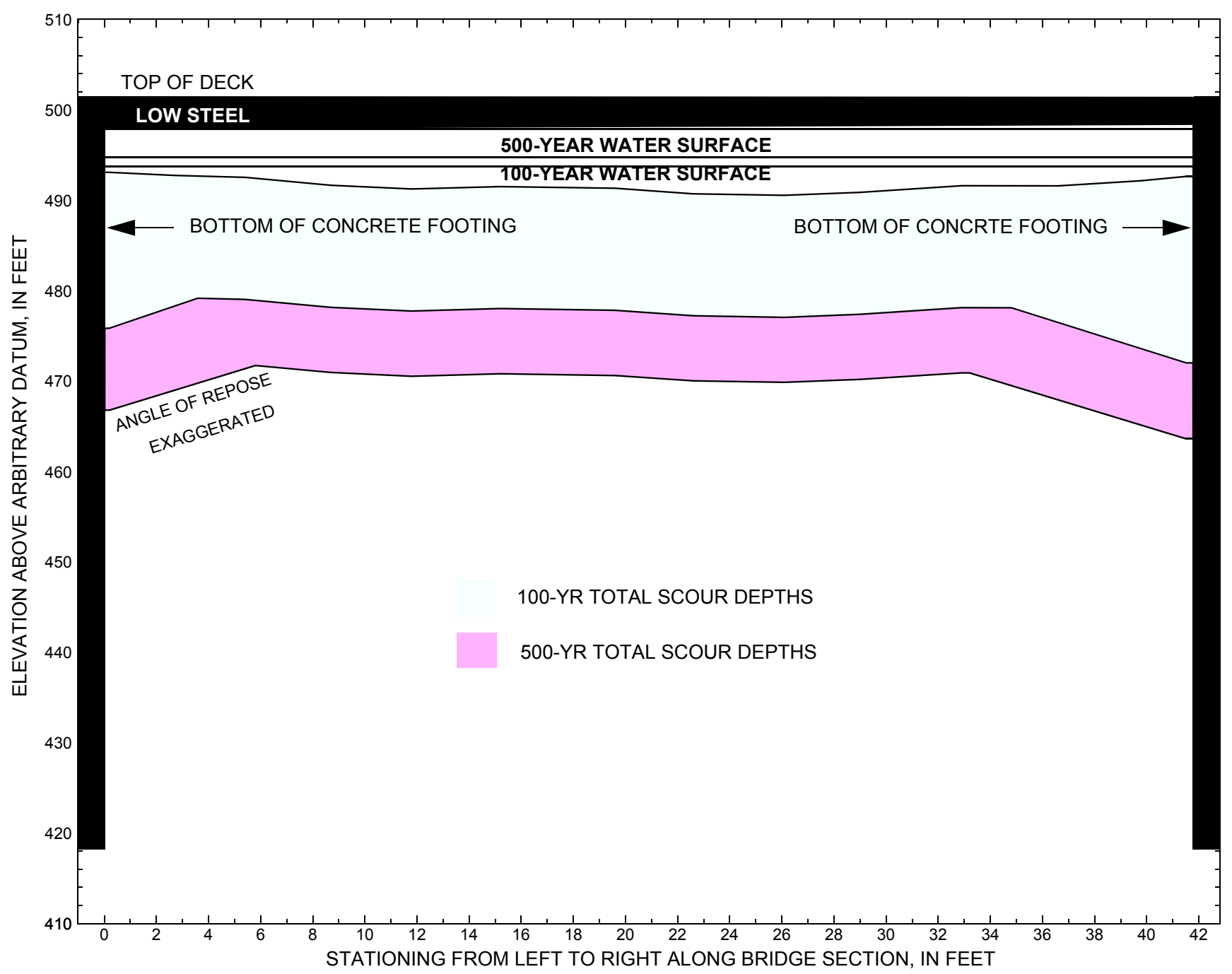

Figure 8. Scour elevations for the 100-year and 500-year discharges at structure FERRTH00190032 on Town Highway 19, crossing the South Slang Little Otter Creek, Ferrisburg, Vermont. 


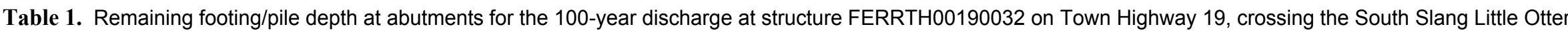
Creek, Ferrisburg, Vermont.

[VTAOT, Vermont Agency of Transportation; --, no data]

\begin{tabular}{|c|c|c|c|c|c|c|c|c|c|c|c|}
\hline Description & Station $^{1}$ & $\begin{array}{l}\text { VTAOT } \\
\text { minimum } \\
\text { bridge seat } \\
\text { elevation } \\
\text { (feet) }\end{array}$ & $\begin{array}{l}\text { Surveyed } \\
\text { minimum } \\
\text { low-chord } \\
\text { elevation }{ }^{2} \\
\text { (feet) }\end{array}$ & $\begin{array}{c}\text { Bottom of } \\
\text { footing/pile } \\
\text { elevation }{ }^{2} \\
\text { (feet) }\end{array}$ & $\begin{array}{c}\text { Channel } \\
\text { elevation at } \\
\text { abutment/ } \\
\text { pier }^{2} \\
\text { (feet) }\end{array}$ & $\begin{array}{l}\text { Contraction } \\
\text { scour depth } \\
\text { (feet) }\end{array}$ & $\begin{array}{l}\text { Abutment } \\
\text { scour } \\
\text { depth } \\
\text { (feet) }\end{array}$ & $\begin{array}{l}\text { Pier } \\
\text { scour } \\
\text { depth } \\
\text { (feet) }\end{array}$ & $\begin{array}{l}\text { Depth of } \\
\text { total scour } \\
\text { (feet) }\end{array}$ & $\begin{array}{c}\text { Elevation of } \\
\text { scour }^{2} \\
\text { (feet) }\end{array}$ & $\begin{array}{c}\text { Remaining } \\
\text { footing/pile } \\
\text { depth } \\
\text { (feet) }\end{array}$ \\
\hline \multicolumn{12}{|c|}{100 -yr. discharge is 770 cubic-feet per second } \\
\hline Left abutment & 0.0 & -- & 497.9 & 418 & 493.1 & 14.0 & 3.2 & -- & 17.2 & 475.9 & 58 \\
\hline Right abutment & 41.8 & -- & 498.3 & 418 & 492.6 & 14.0 & 6.6 & -- & 20.6 & 472.0 & 54 \\
\hline
\end{tabular}

1.Measured along the face of the most constricting side of the bridge.

2.Arbitrary datum for this study.

Table 2. Remaining footing/pile depth at abutments for the 500-year discharge at structure FERRTH00190032 on Town Highway 19, crossing the South Slang Little Otter Creek, Ferrisburg, Vermont.

[VTAOT, Vermont Agency of Transportation; --, no data]

\begin{tabular}{|c|c|c|c|c|c|c|c|c|c|c|c|}
\hline Description & Station $^{1}$ & $\begin{array}{l}\text { VTAOT } \\
\text { minimum } \\
\text { bridge seat } \\
\text { elevation } \\
\text { (feet) }\end{array}$ & $\begin{array}{c}\text { Surveyed } \\
\text { minimum } \\
\text { low-chord } \\
\text { elevation } \\
\text { (feet) }\end{array}$ & $\begin{array}{c}\text { Bottom of } \\
\text { footing/pile } \\
\text { elevation } \\
\text { (feet) }\end{array}$ & $\begin{array}{c}\text { Channel } \\
\text { elevation at } \\
\text { abutment/ } \\
\text { pier }^{2} \\
\text { (feet) }\end{array}$ & $\begin{array}{l}\text { Contraction } \\
\text { scour depth } \\
\text { (feet) }\end{array}$ & $\begin{array}{c}\text { Abutment } \\
\text { scour } \\
\text { depth } \\
\text { (feet) }\end{array}$ & $\begin{array}{l}\text { Pier } \\
\text { scour } \\
\text { depth } \\
\text { (feet) }\end{array}$ & $\begin{array}{l}\text { Depth of } \\
\text { total scour } \\
\text { (feet) }\end{array}$ & $\begin{array}{c}\text { Elevation of } \\
\text { scour }^{2} \\
\text { (feet) }\end{array}$ & $\begin{array}{c}\text { Remaining } \\
\text { footing/pile } \\
\text { depth } \\
\text { (feet) }\end{array}$ \\
\hline \multicolumn{12}{|c|}{500 -yr. discharge is 1,200 cubic-feet per second } \\
\hline Left abutment & 0.0 & -- & 497.9 & 418 & 493.1 & 20.7 & 5.6 & -- & 26.3 & 466.8 & 48 \\
\hline Right abutment & 41.8 & -- & 498.3 & 418 & 492.6 & 20.7 & 8.3 & -- & 29.0 & 463.6 & 45 \\
\hline
\end{tabular}

1.Measured along the face of the most constricting side of the bridge.

2.Arbitrary datum for this study. 


\section{SELECTED REFERENCES}

Arcement, G.J., Jr., and Schneider, V.R., 1989, Guide for selecting Manning's roughness coefficients for natural channels and flood plains: U.S. Geological Survey Water-Supply Paper 2339, 38 p.

Barnes, H.H., Jr., 1967, Roughness characteristics of natural channels: U.S. Geological Survey Water-Supply Paper 1849,213 p.

Benson, M. A., 1962, Factors Influencing the Occurrence of Floods in a Humid Region of Diverse Terrain: U.S. Geological Survey WaterSupply Paper 1580-B, 64 p.

Brown, S.A. and Clyde, E.S., 1989, Design of riprap revetment: Federal Highway Administration Hydraulic Engineering Circular No. 11, Publication FHWA-IP-89-016, 156 p.

Federal Highway Administration, 1983, Runoff estimates for small watersheds and development of sound design: Federal Highway Administration Report FHWA-RD-77-158.

Federal Highway Administration, 1993, Stream Stability and Scour at Highway Bridges: Participant Workbook: Federal Highway Administration Report FHWA-HI-91-011.

Froehlich, D.C., 1989, Local scour at bridge abutments in Ports, M.A., ed., Hydraulic Engineering--Proceedings of the 1989 National Conference on Hydraulic Engineering: New York, American Society of Civil Engineers, p. 13-18.

Hayes, D.C.,1993, Site selection and collection of bridge-scour data in Delaware, Maryland, and Virginia: U.S. Geological Survey WaterResources Investigation Report 93-4017, 23 p.

Interagency Advisory Committee on Water Data, 1982, Guidelines for determining flood flow frequency: U.S. Geological Survey, Bulletin 17B of the Hydrology Subcommittee, 190 p.

Johnson, C.G. and Tasker, G.D.,1974, Progress report on flood magnitude and frequency of Vermont streams: U.S. Geological Survey OpenFile Report 74-130, 37 p.

Lagasse, P.F., Schall, J.D., Johnson, F., Richardson, E.V., Chang, F., 1995, Stream Stability at Highway Structures: Federal Highway Administration Hydraulic Engineering Circular No. 20, Publication FHWA-IP-90-014, 144 p.

Laursen, E.M., 1960, Scour at bridge crossings: Journal of the Hydraulics Division, American Society of Civil Engineers, v. 86, no. HY2, p. 39-53.

Potter, W. D., 1957a, Peak rates of runoff in the Adirondack, White Mountains, and Maine woods area, Bureau of Public Roads

Potter, W. D., 1957b, Peak rates of runoff in the New England Hill and Lowland area, Bureau of Public Roads

Richardson, E.V. and Davis, S.R., 1995, Evaluating scour at bridges: Federal Highway Administration Hydraulic Engineering Circular No. 18, Publication FHWA-IP-90-017, 204 p.

Richardson, E.V., Simons, D.B., and Julien, P.Y., 1990, Highways in the river environment: Federal Highway Administration Publication FHWA-HI-90-016.

Ritter, D.F., 1984, Process Geomorphology: W.C. Brown Co., Debuque, Iowa, 603 p.

Shearman, J.O., 1990, User's manual for WSPRO--a computer model for water surface profile computations: Federal Highway Administration Publication FHWA-IP-89-027, 187 p.

Shearman, J.O., Kirby, W.H., Schneider, V.R., and Flippo, H.N., 1986, Bridge waterways analysis model; research report: Federal Highway Administration Publication FHWA-RD-86-108, 112 p.

Talbot, A.N., 1887, The determination of water-way for bridges and culverts.

dU.S. Geological Survey, 1980, Westport, Vermont 7.5 X 15 Minute Series quadrangle map: U.S. Geological Survey Topographic Maps, Scale 1:25,000. 


\section{APPENDIX A: \\ WSPRO INPUT FILE}




\section{WSPRO INPUT FILE}

GR

GR

GR

GR

GR

GR

GR

GR

$\mathrm{N}$

SA

*

XS

*

*

BR

GR

GR

GR

GR

GR

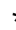

$\mathrm{CD}$

$\mathrm{N}$

*

*

$\mathrm{XR}$

GR

GR

GR

GR

GR

GR

GR

GR

GR

GR

GR

GR

$\mathrm{N}$

SA
U.S. Geological Survey WSPRO Input File ferr032.wsp

Hydraulic analysis for structure FERRTH00190032 Date: 27-OCT-97

Br 32 on Hawkins Rd over South Slang Little Otter Crk Ferrisburg, VT

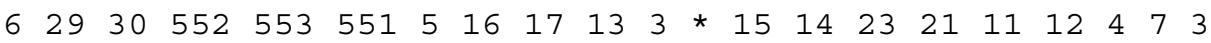

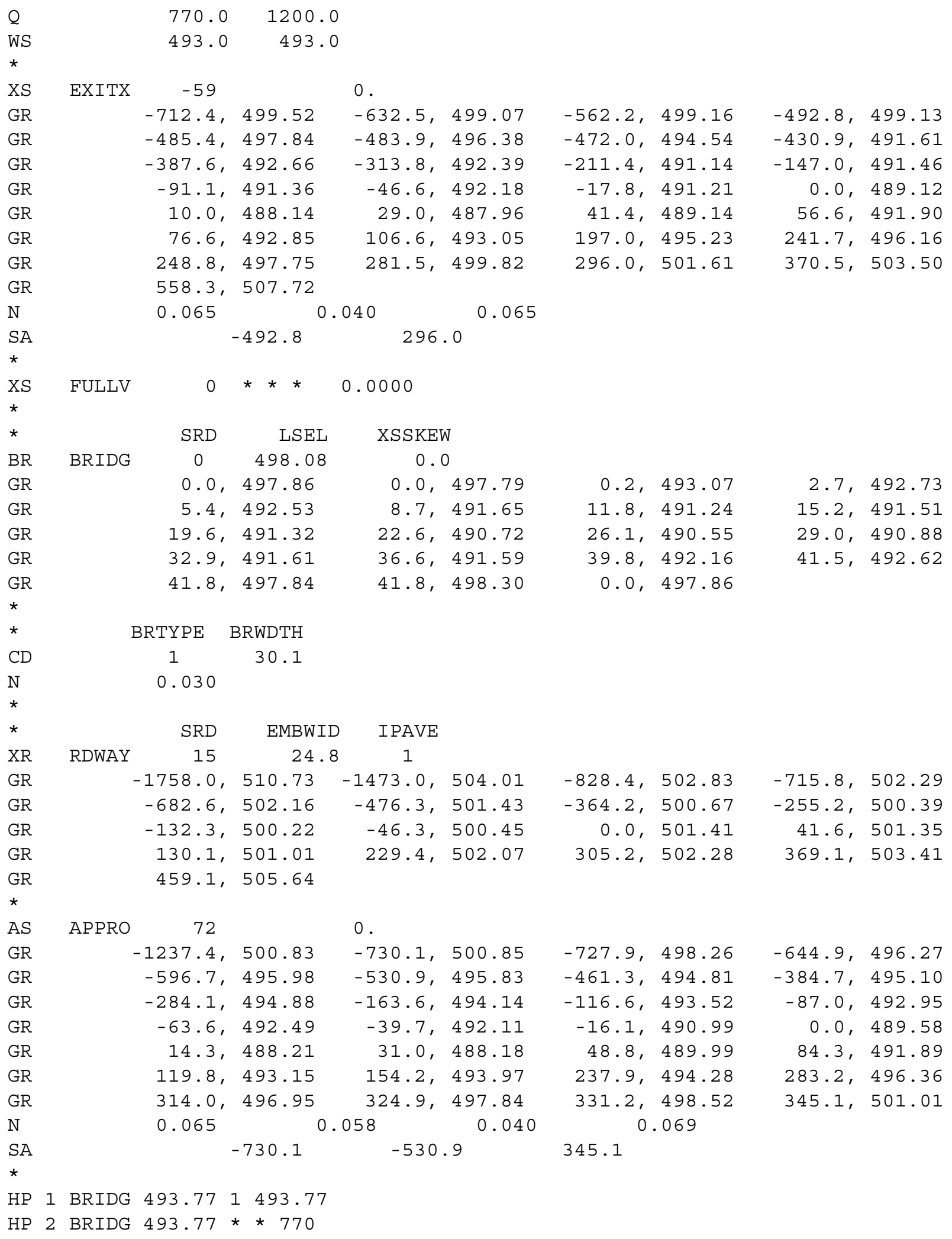

HP 1 BRIDG $493.77 \quad 1 \quad 493.77$

HP 2 BRIDG 493.77 * * 770

HP 1 APPRO 495.261495 .26 


\section{APPENDIX B: \\ WSPRO OUTPUT FILE}


WSPRO OUTPUT FILE

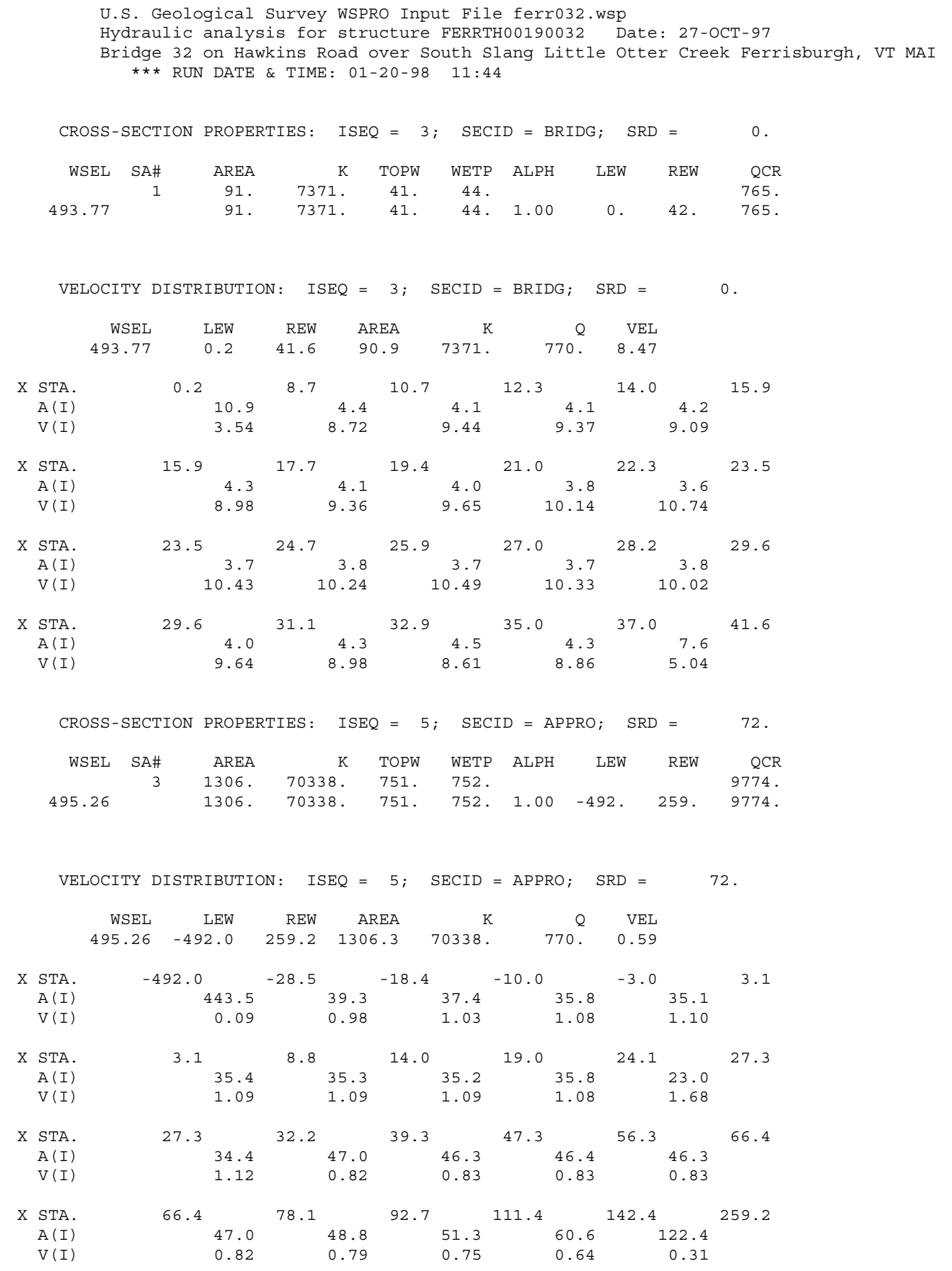


WSPRO OUTPUT FILE (continued)

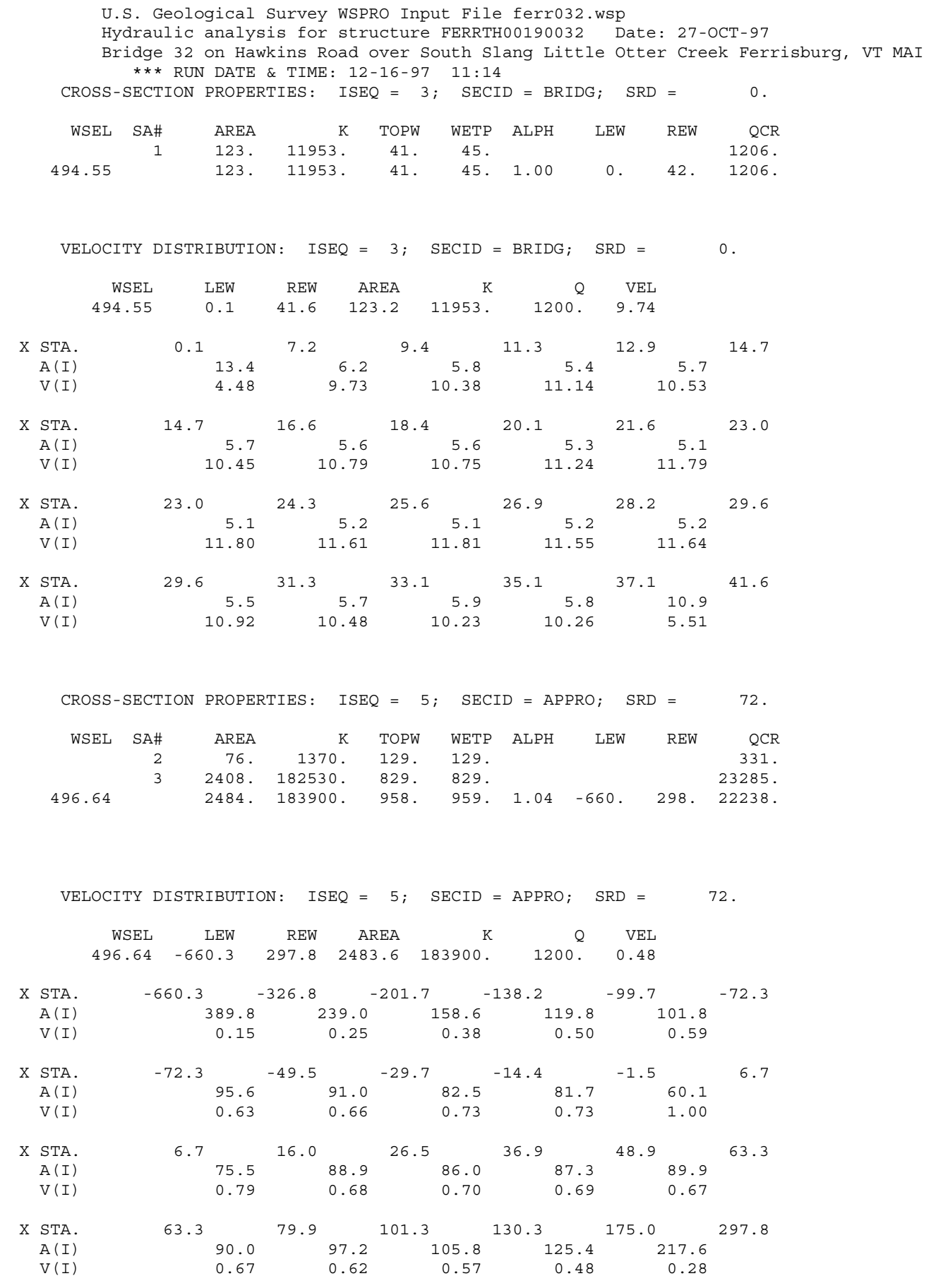


WSPRO OUTPUT FILE (continued)

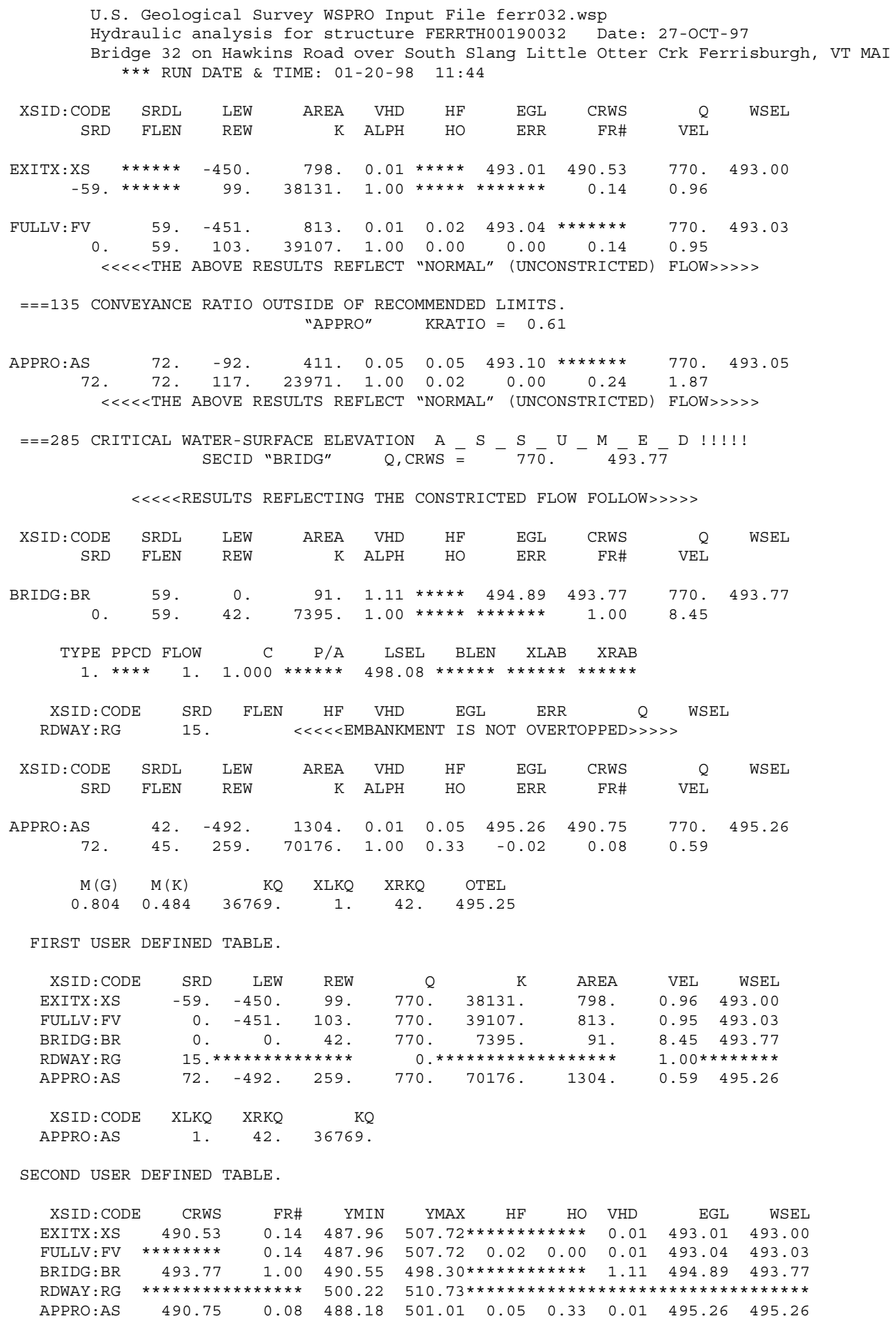


WSPRO OUTPUT FILE (continued)

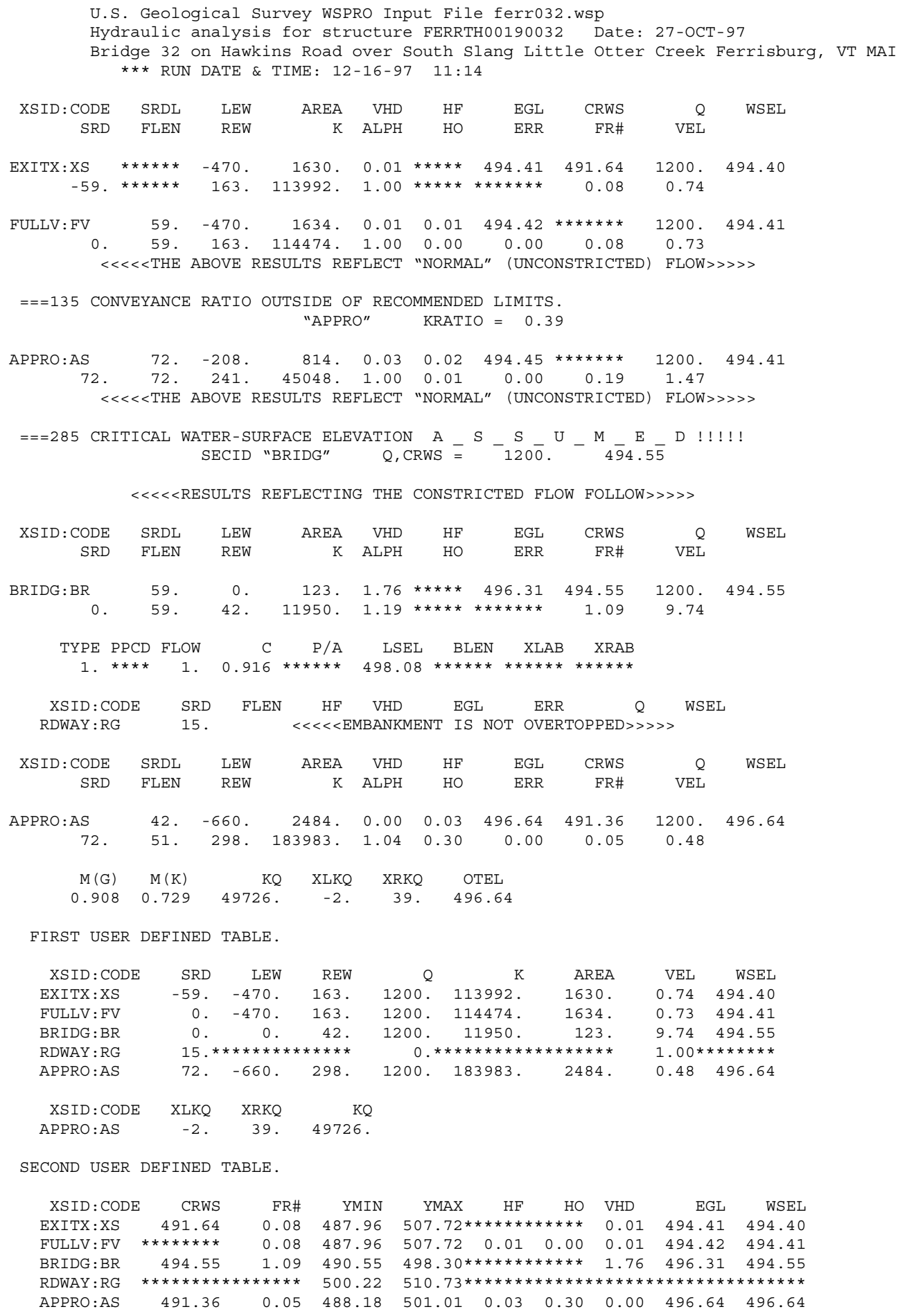




\section{APPENDIX C: \\ HISTORICAL DATA FORM}




\section{Structure Number FERRTH00190032}

\section{General Location Descriptive}

Data collected by (First Initial, Full last name) $\underline{\text { L. }}$. Medalie

Date $(M M / D D / Y Y)+12 / 11 / 95$

Highway District Number (I - 2; nn) $\mathbf{0 5}$

Town (FIPS place code; I - 4; nnnnn) $\mathbf{2 6 2 7 5}$

Waterway (I - 6) Hawkins Slang Brook

Route Number $\underline{\text { TH } 19}$

Topographic Map Westport

Latitude (I - 16; nnnn.n) $\mathbf{4 4 1 3 3}$
County (FIPS county code; I - 3; nnn)

Mile marker (I - 11; nnn.nnn) $\mathbf{0 0 0 0 0 0}$

Road Name ( $I$ - 7): Hawkins Road

Vicinity $(I-9) 1.9$ miles to jet. with TH5

Hydrologic Unit Code: $\mathbf{0 2 0 1 0 0 0 2}$

Longitude (i - 17; nnnnn.n) 73164

\section{Select Federal Inventory Codes}

FHWA Structure Number (I - 8) $\mathbf{1 0 0 1 0 5 0 0 3 2 0 1 0 5}$

Maintenance responsibility $(I-21 ; n n) \_$03 $\quad$ Maximum span length $(I-48 ; n n n n) \underline{\mathbf{0 0 4 2}}$

Year built (I - 27; YYYY) 1966

Structure length (I - 49; nnnnnn) $\underline{\mathbf{0 0 0 0 4 5}}$

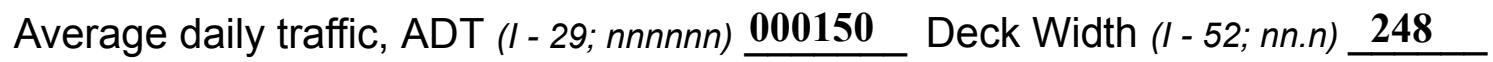

Year of ADT (I - 30; YY) $\mathbf{9 2}$

Channel \& Protection $(I-61 ; n) \underline{\mathbf{5}}$

Opening skew to Roadway $(I-34 ; n n) \quad \mathbf{0 0}$

Waterway adequacy $(I-71 ; n) \mathbf{4}$

Operational status $(I-41 ; X) \quad \mathbf{A}$

Underwater Inspection Frequency (I - 92B; XYY) Y48

Structure type (I- 43; nnn) $\mathbf{5 0 5}$

Year Reconstructed (I - 106) $\mathbf{0 0 0 0}$

Approach span structure type $(I-44 ; n n n) \quad \mathbf{0 0 0}$

Clear span $(n n n . n f t) \underline{40}$

Number of spans (I - 45; nnn) $\underline{\mathbf{0 0 1}}$

Vertical clearance from streambed (nnn.n ft) $\underline{\mathbf{7 . 5}}$

Number of approach spans (I - 46; nnnn) $\underline{\mathbf{0 0 0 0}}$ Waterway of full opening $\left(n n n . n \mathrm{ft}^{2}\right) \underline{\mathbf{3 0 0}}$

Comments:

According to the structural inspection report dated 9/28/94, the structure consists of 6 concrete box beams with a concrete overlay. The abutments are concrete. The abutments have overall light to heavy scaling. Portions of the substructure stem and footings are inaccessible due to the depth of the water. There was approximately $2 \mathrm{ft}$ of freeboard at the time of the inspection. The channel is very wide through this locations, with large areas of marshland. There is stone fill along the front of the abutments. Contraction scour through the channel is noted. There is poor hydraulic adequacy because of the low height. 


\section{Bridge Hydrologic Data}

Is there hydrologic data available? $\underline{\mathbf{N}}$ if No, type ctrl-n $h \quad$ VTAOT Drainage area $\left(m i^{2}\right)$ : -

Terrain character:

Stream character \& type: -

Streambed material: Silt to sand.

Discharge Data (cfs): $\quad \mathrm{Q}_{2.33}$

$$
\mathrm{Q}_{50}-
$$

Record flood date $(M M / D D / Y Y):-$

$$
\begin{array}{ll}
Q_{10} \_- & Q_{25}- \\
Q_{100 \_-} & Q_{500}-
\end{array}
$$

Water surface elevation $(f t):-$

Estimated Discharge (cfs): Velocity at $\mathrm{Q}$ $(\mathrm{ft} / \mathrm{s}):$

Ice conditions (Heavy, Moderate, Light) : -

Debris (Heavy, Moderate, Light):

The stage increases to maximum highwater elevation (Rapidly, Not rapidly):

The stream response is (Flashy, Not flashy):

Describe any significant site conditions upstream or downstream that may influence the stream's stage: On the cross-section sketch of the DS bridge face dated 10-15-92, a beaver dam is noted against the left abutment.

Watershed storage area (in percent): _ _ \%

The watershed storage area is: - (1-mainly at the headwaters; 2- uniformly distributed; 3-immediatly upstream oi the site)

Water Surface Elevation Estimates for Existing Structure:

\begin{tabular}{|l|l|l|l|l|l|}
\hline Peak discharge frequency & $Q_{2.33}$ & $Q_{10}$ & $Q_{25}$ & $Q_{50}$ & $Q_{100}$ \\
Water surface elevation (ft) $)$ & - & - & - & - & - \\
Velocity $(\mathrm{ft} / \mathrm{sec})$ & - & - & - & - & - \\
\hline
\end{tabular}

Long term stream bed changes: -

Is the roadway overtopped below the $\mathrm{Q}_{100}$ ? (Yes, No, Unknown): $\mathbf{U}$ Frequency: Relief Elevation $(f t)$ :

Discharge over roadway at $Q_{100}\left(f t^{3} / \mathrm{sec}\right)$ :

Are there other structures nearby? (Yes, No, Unknown): $\underline{\mathbf{U}}$ Upstream distance (miles): Town: If No or Unknown, type ctrl-n os Highway No. : Structure No. : Year Built:

Clear span (ft): Clear Height (ft): Full Waterway $\left(f t^{2}\right)$ : 
Downstream distance (miles): Town: Year Built:

Highway No. : Structure No. : Structure Type:

Clear span (ft): Clear Height $(f t)$ : Full Waterway $\left(f^{2}\right)$ :

Comments:

According to the underwater bridge inspection report dated 7/7/93, the bottom is silt-sand and the water is dark with poor visibility and weeds.

Also, the top of the footing is exposed on the right abutment.

\section{USGS Watershed Data}

Watershed Hydrographic Data

Drainage area $(D A)$

8.02 $\mathrm{mi}^{2}$ Lake/pond/swamp area 0.048 $\mathrm{mi}^{2}$

Watershed storage (ST) 0.06 $\%$

Bridge site elevation 98

Main channel length 7.35 $\mathrm{ft}$ Headwater elevation 290 $\mathrm{ft}$ $10 \%$ channel length elevation $\mathbf{9 8}$ $\mathrm{ft} \quad 85 \%$ channel length elevation 189

Main channel slope $(S)$

(S) 16.51 $\mathrm{ft} / \mathrm{mi}$

Watershed Precipitation Data

Average site precipitation in Average headwater precipitation in

Maximum 2yr-24hr precipitation event $(124,2)$ in

Average seasonal snowfall (Sn) $\mathrm{ft}$ 


\section{Bridge Plan Data}

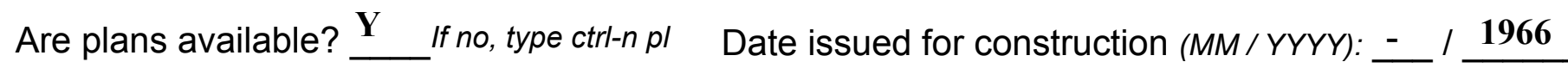
Project Number -

Minimum channel bed elevation: $\underline{90.5}$

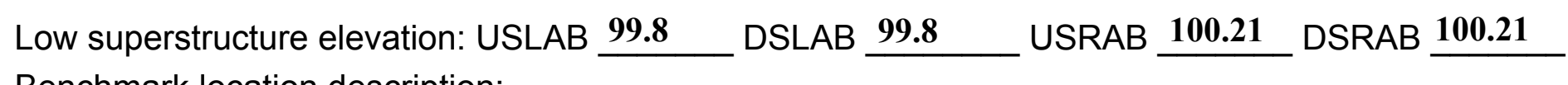

Benchmark location description:

The low superstructure elevations are the top of the abutment corner elevations from the bridge plans. BM \#1 (spike in root or trunk) elevation $100 \mathrm{ft}$ (assumed), in a $36 \mathrm{in} \mathrm{elm,} 200 \mathrm{ft}$ from the right side of the bridge at the DS end.

Reference Point (MSL, Arbitrary, Other): Arbitrary Datum (NAD27, NAD83, Other):

Foundation Type: 2 (1-Spreadfooting; 2-Pile; 3- Gravity; 4-Unknown)

If 1 : Footing Thickness $\mathbf{3} \quad$ Footing bottom elevation: $\underline{\mathbf{8 8 . 0}}$

If 2: Pile Type: 1 (1-Wood; 2-Steel or metal; 3-Concrete) Approximate pile driven length: $\mathbf{7 0 *}$

If 3: Footing bottom elevation: -

Is boring information available? $\underline{\mathbf{Y}}$ If no, type ctrl-n bi Number of borings taken: $\underline{\mathbf{3}}$

Foundation Material Type: 1 (1-regolith, 2-bedrock, 3-unknown)

Briefly describe material at foundation bottom elevation or around piles:

The B-10 boring near center of channel shows that refusal on rock is reached at about 125' below bottom of the stream bed. Clay constitutes most of the material above rock.

Comments:

*The plans indicate estimated length, $70 \mathrm{ft}$ each pile. Office memo in folder contains note that "local resident says that abutments are on $90 \mathrm{ft}$ piles. There was ledge at $132 \mathrm{ft}$." 


\section{Cross-sectional Data}

Is cross-sectional data available? $\underline{\mathbf{Y}}$

If no, type ctrl-n xs

Source (FEMA, VTAOT, Other)? VTAOT

This cross section is at the downstream face. The low chord data is from the survey log done Comments: for this report on 7/2/96. The low chord to bed length data is from the sketch attached to a bridge inspection report dated 9/28/94. The sketch was done on 10/15/92.

\begin{tabular}{|l|l|l|l|l|l|l|l|l|l|l|l|}
\hline Station & $\mathbf{0}$ & $\mathbf{1 6 . 1}$ & $\mathbf{2 4 . 6}$ & $\mathbf{4 0 . 8}$ & - & - & - & - & - & - \\
\hline Feature & RAB & - & - & LAB & - & - & - & - & - & - \\
\hline $\begin{array}{l}\text { Low chord } \\
\text { elevation }\end{array}$ & $\mathbf{4 9 8 . 3}$ & $\mathbf{4 9 8 . 1}$ & $\mathbf{4 9 8 . 1}$ & $\mathbf{4 9 7 . 9}$ & - & - & - & - & - & - & - \\
\hline $\begin{array}{l}\text { Bed } \\
\text { elevation }\end{array}$ & $\mathbf{4 9 2 . 5}$ & $\mathbf{4 9 1 . 1}$ & $\mathbf{4 9 1 . 4}$ & $\mathbf{4 9 3 . 1}$ & - & - & - & - & - & - & - \\
\hline $\begin{array}{l}\text { Low chord } \\
\text { to bed }\end{array}$ & $\mathbf{5 . 8}$ & $\mathbf{7 . 0}$ & $\mathbf{6 . 7}$ & $\mathbf{4 . 8}$ & - & - & - & - & - & - & - \\
\hline \begin{tabular}{l} 
Station \\
\hline Feature
\end{tabular} & - & - & - & - & - & - & - & - & - & - & - \\
\hline $\begin{array}{l}\text { Low chord } \\
\text { elevation }\end{array}$ & - & - & - & - & - & - & - & - & - & - \\
\hline $\begin{array}{l}\text { Bed } \\
\text { elevation }\end{array}$ & - & - & - & - & - & - & - & - & - & - \\
\hline $\begin{array}{l}\text { Low chord } \\
\text { to bed }\end{array}$ & - & - & - & - & - & - & - & - & - & - \\
\hline
\end{tabular}

Source (FEMA, VTAOT, Other)?

Comments: -

\begin{tabular}{|l|l|l|l|l|l|l|l|l|l|l|l|l|}
\hline Station & - & - & - & - & - & - & - & - & - & - \\
\hline Feature & - & - & - & - & - & - & - & - & - & - \\
\hline $\begin{array}{l}\text { Low chord } \\
\text { elevation }\end{array}$ & - & - & - & - & - & - & - & - & - & - & - \\
\hline $\begin{array}{l}\text { Bed } \\
\text { elevation }\end{array}$ & - & - & - & - & - & - & - & - & - & - \\
\hline $\begin{array}{l}\text { Low chord } \\
\text { to bed }\end{array}$ & - & - & - & - & - & - & - & - & - & - & - \\
\hline \begin{tabular}{l} 
Station \\
\hline \begin{tabular}{l} 
Feature \\
\hline
\end{tabular}
\end{tabular}$-$ & - & - & - & - & - & - & - & - & - & - & - \\
\hline $\begin{array}{l}\text { Low chord } \\
\text { elevation }\end{array}$ & - & - & - & - & - & - & - & - & - & - \\
\hline $\begin{array}{l}\text { Bed } \\
\text { elevation }\end{array}$ & - & - & - & - & - & - & - & - & - & - \\
\hline $\begin{array}{l}\text { Low chord } \\
\text { to bed }\end{array}$ & - & - & - & - & - & - & - & - & - & - \\
\hline
\end{tabular}


APPENDIX D:

LEVEL I DATA FORM 
U. S. Geological Survey

Bridge Field Data Collection and Processing Form

Qa/Qc Check by: $\mathbf{R B}$

Date: $10 / 25 / 96$

\section{Structure Number}

FERRTH00190032

Computerized by: $\underline{\mathbf{R B}}$ Date: $10 / 28 / 96$

Reviewd by: MAL Date: 10/30/97

\section{A. General Location Descriptive}

1. Data collected by (First Initial, Full last name) $\mathbf{E}$. Wild

2. Highway District Number $\mathbf{0 5}$

County Addison (001)

Waterway $(I-6)$ South Slang Little Otter Creek

Route Number TH019

Date $(M M / D D / Y Y) \underline{\mathbf{0 7}} / \underline{\mathbf{0 2}} / \underline{1996}$

3. Descriptive comments:

Mile marker -

Town Ferrisburg (26275)

Road Name Hawkins Road

Hydrologic Unit Code: $\mathbf{0 2 0 1 0 0 0 2}$

The site is located 1.9 miles from the junction with Town Highway 5.

\section{B. Bridge Deck Observations}
4. Surface cover..
RBUS 7
LBDS 7
RBDS 7
Overall 7

(2b us, ds,lb,rb: 1- Urban; 2- Suburban; 3- Row crops; 4- Pasture; 5- Shrub- and brushland; 6- Forest; 7- Wetland)
5. Ambient water surface... US 1
UB 1
DS 1
(1- pool; 2- riffle)

6. Bridge structure type 1 (1- single span; 2- multiple span; 3- single arch; 4- multiple arch; 5-cylindrical culvert; 6- box culvert; or 7- other)
7. Bridge length $\mathbf{4 5}$
(feet)
Span length $\underline{\mathbf{4 2}}$
(feet)
Bridge width 24.8 (feet)

\section{Road approach to bridge:}
8. LB 0
RB 2
( 0 even, 1- lower, 2- higher)
9. LB
RB 1
(1-Paved, 2- Not paved)

10. Embankment slope (run / rise in feet / foot)

US left

US right

\begin{tabular}{|c|c|c|c|}
\hline \multicolumn{2}{|c|}{ Protection } & \multirow{2}{*}{ 13.Erosion } & 14.Severity \\
\hline 11.Type & 12.Cond. & $\mathbf{0}$ & - \\
\hline $\mathbf{1}$ & $\mathbf{1}$ & $\mathbf{0}$ & - \\
$\mathbf{1}$ & $\mathbf{1}$ & $\mathbf{0}$ & - \\
\hline $\mathbf{1}$ & $\mathbf{1}$ & $\mathbf{3}$ & $\mathbf{1}$ \\
\hline $\mathbf{1}$ & $\mathbf{1}$ & $\mathbf{3}$ & $\mathbf{1}$ \\
\hline
\end{tabular}

Bank protection types: 0- none; 1- < 12 inches,

2- $<36$ inches; $3-<48$ inches;

4- < 60 inches; 5- wall / artificial levee

Bank protection conditions: 1- good; 2- slumped;

3- eroded; 4- failed

Erosion: 0 - none; 1- channel erosion; 2 -

road wash; 3- both; 4- other

Erosion Severity: 0 - none; 1- slight; 2- moderate; 3- severe

\section{Channel approach to bridge (BF):}

15. Angle of approach: $\mathbf{0}$

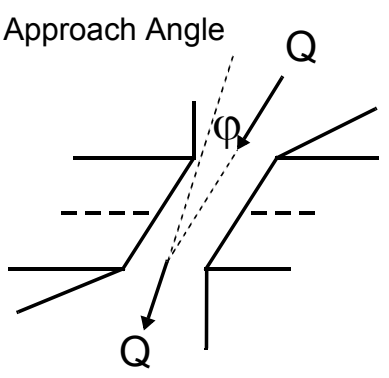

17. Channel impact zone 1:

Where? $(L B, R B)$

Range? feet -

Channel impact zone 2:

Where? $(L B, R B)$

Range? - $\quad$ feet -

(US, UB, DS) to feet Impact Severity: 0- none to very slight; 1- Slight; 2- Moderate; 3- Severe

16. Bridge skew: 5 Bridge Skew Angle

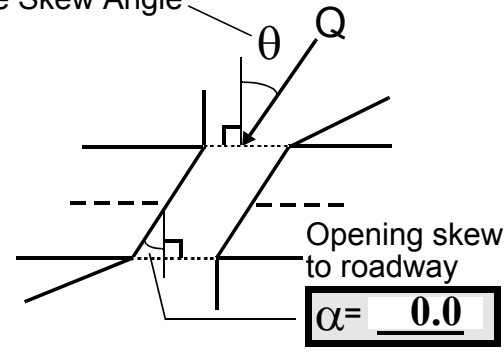

Exist? $\underline{\mathbf{N}}(\mathrm{Y}$ or $N)$

Severity (US, UB, DS) to feet -

Exist? $\mathbf{N} \quad($ Yor $N)$

Severity - 
18. Bridge Type: $1 \mathbf{b}$

1a- Vertical abutments with wingwalls

$1 \mathrm{~b}$ - Vertical abutments without wingwalls

2- Vertical abutments and wingwalls, sloping embankment Wingwalls parallel to abut. face

3- Spill through abutments

4- Sloping embankment, vertical wingwalls and abutments

Wingwall angle less than $90^{\circ}$.

19. Bridge Deck Comments (surface cover variations, measured bridge and span lengths, bridge type variations, approach overflow width, etc.)

4. The main channel thalweg upstream and downstream meanders through a wetland. (see sketch)

13. There is no roadwash and the channel is protected with stone fill along the road embankments. However, at the bridge there is erosion of the material along the downstream road embankment. Debris has filled in the void behind the DS right road embankment. The sand has been washed away undermining $0.4 \mathrm{ft}$ under the pavement near the DS left road embankment.

\section{Upstream Channel Assessment}

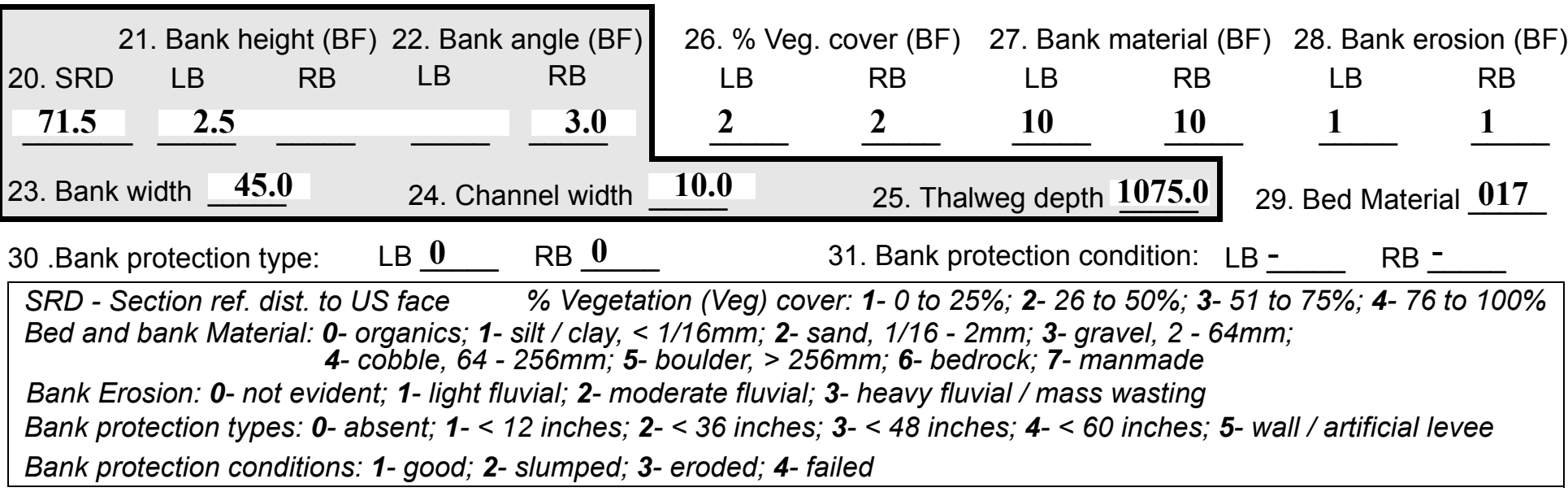

32. Comments (bank material variation, minor inflows, protection extent, etc.):

29. Stone fill extends to $28 \mathrm{ft}$ US and across the US bridge face in the channel. 
33.Point/Side bar present? $\mathbf{N}(Y$ or $N$. if $N$ type ctrl-n pb)34. Mid-bar distance: -

35. Mid-bar width: -

36. Point bar extent: feet (US, UB) to feet (US, UB, DS) positioned $\%$ LB to $\% \mathrm{RB}$

37. Material: -

38. Point or side bar comments (Circle Point or Side; Note additional bars, material variation, status, etc.):

NO POINT BARS

39. Is a cut-bank present? $\underline{\mathbf{N}}$ (Y or if $\mathrm{N}$ type ctrl-n cb)

40. Where? - $\quad$ (LB or RB)

41. Mid-bank distance: -

42. Cut bank extent: feet (US, UB) to feet (US, UB, DS)

43. Bank damage: (1- eroded and/or creep; 2- slip failure; 3- block failure)

44. Cut bank comments (eg. additional cut banks, protection condition, etc.):

NO CUT BANKS

45. Is channel scour present? $\mathbf{Y}$ ( $Y$ or if $N$ type ctrl-n cs)

47. Scour dimensions: Length $\mathbf{5 7}$

Width 40

Depth : 3.5

46. Mid-scour distance: 62

48. Scour comments (eg. additional scour areas, local scouring process, etc.):

The total depth is $9.5 \mathrm{ft}$. The thalweg is assumed to be $6 \mathrm{ft}$.

\section{Are there major confluences? $\mathbf{N}$}

51. Confluence 1: Distance Confluence 2: Distance 52. Enters on Enters on 54. Confluence comments (eg. confluence name):

NO MAJOR CONFLUENCES
50. How many? -

53. Type(1-perennial; 2- ephemeral)

Type (1-perennial; 2-ephemeral) ( $L B$ or $R B)$

\section{Under Bridge Channel Assessment}

55. Channel restraint (BF)? LB 2

\begin{tabular}{|llll}
\hline \multicolumn{2}{|c}{ 56. Height (BF) } & \multicolumn{2}{c}{57 Angle (BF) } \\
LB & RB & LB & RB \\
$\mathbf{1 0 5 8 . 5}$ & & & $\mathbf{1 0 . 0}$ \\
\hline
\end{tabular}
(1- natural bank; 2- abutment; 3- artificial levee)

58. Bank width (BF) -

59. Channel width \begin{tabular}{lclc}
\multicolumn{2}{l}{ 61. Material (BF) } & \multicolumn{3}{l}{ 62. Erosion (BF) } \\
LB & RB & LB & RB \\
$\mathbf{2}$ & $\mathbf{7}$ & & $\mathbf{7}$ \\
\hline
\end{tabular}

Bed and bank Material:

60. Thalweg depth $\lcm{90.0}$

63. Bed Material -

Bed and bank Material: 0- organics; 1- silt / clay, < 1/16mm; 2- sand, 1/16
5- boulder, > 256mm; 6- bedrock; 7- manmade

Bank Erosion: 0- not evident; 1- light fluvial; 2- moderate fluvial; 3- heavy fluvial / mass wasting

64. Comments (bank material variation, minor inflows, protection extent, etc.):

173

63. The bed material is clay and stone fill extending across the entire bridge face on the US end. Silt, clay, and gravel exists DS to the edge of the abutments where the abutment side walls begin then there is slumped stone fill from the corners to $10 \mathrm{ft}$ DS. 
65. Debris and Ice Is there debris accumulation?

(Yor $N)$ 66. Where? $\underline{Y}$

(1- Upstream; 2- At bridge; 3- Both)

67. Debris Potential $\underline{3}$

( 1- Low; 2- Moderate; 3- High)

68. Capture Efficiency 2

(1-Low; 2- Moderate; 3- High)

69. Is there evidence of ice build-up? 2

Ice Blockage Potential $\mathbf{N}$

(1-Low; 2- Moderate; 3- High)

70. Debris and Ice Comments:

2

66. The debris is in the form of large trees accumulating on the US and DS edges of the road.

67. There is moderate debris potential due to vegetation along the marsh banks and in the marsh itself.

\begin{tabular}{|l|c|c|c|c|c|c|c|c|}
\hline Abutments & $\begin{array}{c}\text { 71. Attack } \\
\angle \text { (BF) }\end{array}$ & $\begin{array}{c}72 \text {. Slope } \angle \\
\text { (Qmax) }\end{array}$ & $\begin{array}{c}\text { 73. Toe } \\
\text { loc. (BF) }\end{array}$ & $\begin{array}{c}\text { 74. Scour } \\
\text { Condition }\end{array}$ & $\begin{array}{c}75 . \text { Scour } \\
\text { depth }\end{array}$ & $\begin{array}{c}\text { 76. Exposure } \\
\text { depth }\end{array}$ & 77. Material & 78. Length \\
\hline LABUT & & $\mathbf{0}$ & $\mathbf{9 0}$ & $\mathbf{2}$ & $\mathbf{0}$ & $\mathbf{0}$ & $\mathbf{0}$ & $\mathbf{9 0 . 0}$ \\
\hline RABUT & $\mathbf{1}$ & $\mathbf{5}$ & $\mathbf{9 0}$ & & & $\mathbf{2}$ & $\mathbf{2}$ & $\mathbf{4 2 . 0}$ \\
\hline
\end{tabular}

Pushed: $L B$ or RB

Toe Location (Loc.): 0- even, 1- set back, 2- protrudes

Scour cond.: 0- not evident; 1- evident (comment); 2- footing exposed; 3-undermined footing; 4- piling exposed; 5- settled; 6- failed

Materials: 1- Concrete; 2- Stone masonry or drywall; 3- steel or metal; 4- wood

79. Abutment comments (eg. undermined penetration, unusual scour processes, debris, etc.):

2

.5

1

74. The scour is on the right side from the US bridge face to $17 \mathrm{ft}$ US. The scour hole width is $9 \mathrm{ft}$ and the depth is $2 \mathrm{ft}$ at $7 \mathrm{ft}$ US. The assumed thalweg depth is $6 \mathrm{ft}$.

80. Wingwalls:

Exist? Material? Scour Scour Exposure $\begin{aligned} & 81 . \\ & \text { Angle? Length? }\end{aligned}$ Condition? depth? depth?

USLWW:

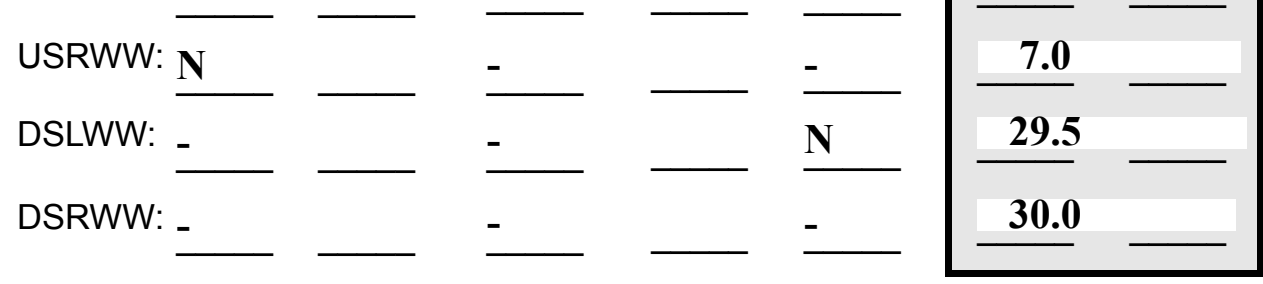

Wingwall materials: 1- Concrete; 2- Stone masonry or drywall; 3- steel or metal; 4- wood

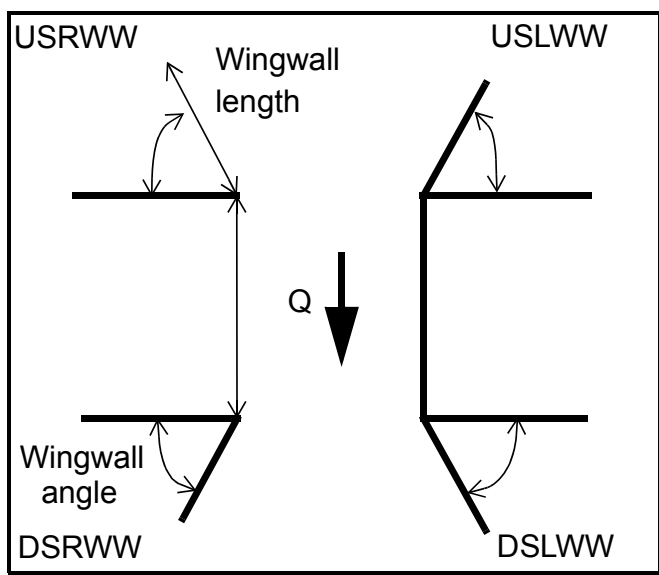

82. Bank / Bridge Protection:

\begin{tabular}{|l|l|l|l|l|l|l|l|c|}
\hline Location & USLWW & USRWW & LABUT & RABUT & LB & RB & DSLWW & DSRWW \\
\hline Type & - & - & N & - & - & - & $\mathbf{1}$ & $\mathbf{1}$ \\
\hline Condition & $\mathbf{N}$ & - & - & - & - & - & $\mathbf{1}$ & $\mathbf{1}$ \\
\hline Extent & - & - & - & - & - & $\mathbf{1}$ & $\mathbf{1}$ & - \\
\hline
\end{tabular}

Bank / Bridge protection types: 0- absent; 1- < 12 inches; 2- < 36 inches; 3- < 48 inches; 4- < 60 inches; 
83. Wingwall and protection comments (eg. undermined penetration, unusual scour processes, etc.):

-
-
-
-
-
-
-
-
-

\section{Piers:}

84. Are there piers? Th (Y or if $N$ type ctrl-n pr)

\begin{tabular}{|l|l|l|l|l|l|l|l|}
\hline \multirow{2}{*}{$\begin{array}{l}85 . \\
\text { Pier no. }\end{array}$} & \multicolumn{3}{|c|}{ width (w) feet } & \multicolumn{3}{c|}{ elevation (e) feet } \\
\cline { 2 - 9 } & w1 & w2 & w3 & e@w1 & e@w2 & e@w3 \\
\hline Pier 1 & - & - & - & - & - & - \\
\hline Pier 2 & - & - & - & - & - & - \\
\hline Pier 3 & - & - & - & - & - & - \\
\hline Pier 4 & - & - & - & - & - & - \\
\hline
\end{tabular}

\begin{tabular}{|l|l|l|l|l|}
\hline Level 1 Pier Descr. & \multicolumn{1}{|c|}{1} & \multicolumn{1}{|c|}{2} & 3 & \multicolumn{1}{|l|}{} \\
\hline 86. Location (BF) & e road & side & & - \\
\hline 87. Type & emb & walls & N & - \\
\hline 88. Material & ank- &. & - & - \\
\hline 89. Shape & ment & & - & - \\
\hline 90. Inclined? & stone & & - & - \\
\hline 91. Attack $\angle$ (BF) & fill is & & - & - \\
\hline 92. Pushed & exte & & - & - \\
\hline 93. Length (feet) & - & - & - & - \\
\hline 94. \# of piles & nsive & & - & - \\
\hline 95. Cross-members & alon & & - & - \\
\hline 96. Scour Condition & g the & & - & - \\
\hline 97. Scour depth & abut & & - & - \\
\hline 98. Exposure depth & ment & & - & - \\
\hline
\end{tabular}

LFP, LTB, LB, MCL, MCM, MCR, RB, RTB, RFP

1- Solid pier, 2- column, 3- bent

1-Wood; 2- concrete; 3- metal; 4- stone

1- Round; 2- Square; 3- Pointed

Y-yes; $N-$ no

$L B$ or $R B$

0- none; 1- laterals; 2- diagonals; 3- both

0- not evident; 1- evident (comment);

2- footing exposed; 3- piling exposed;

4- undermined footing; 5- settled; 6- failed 
99. Pier comments (eg. undermined penetration, protection and protection extent, unusual scour processes, etc.):

-
-
-
-
-
-
-
-
-
-

100.

\section{E. Downstream Channel Assessment}

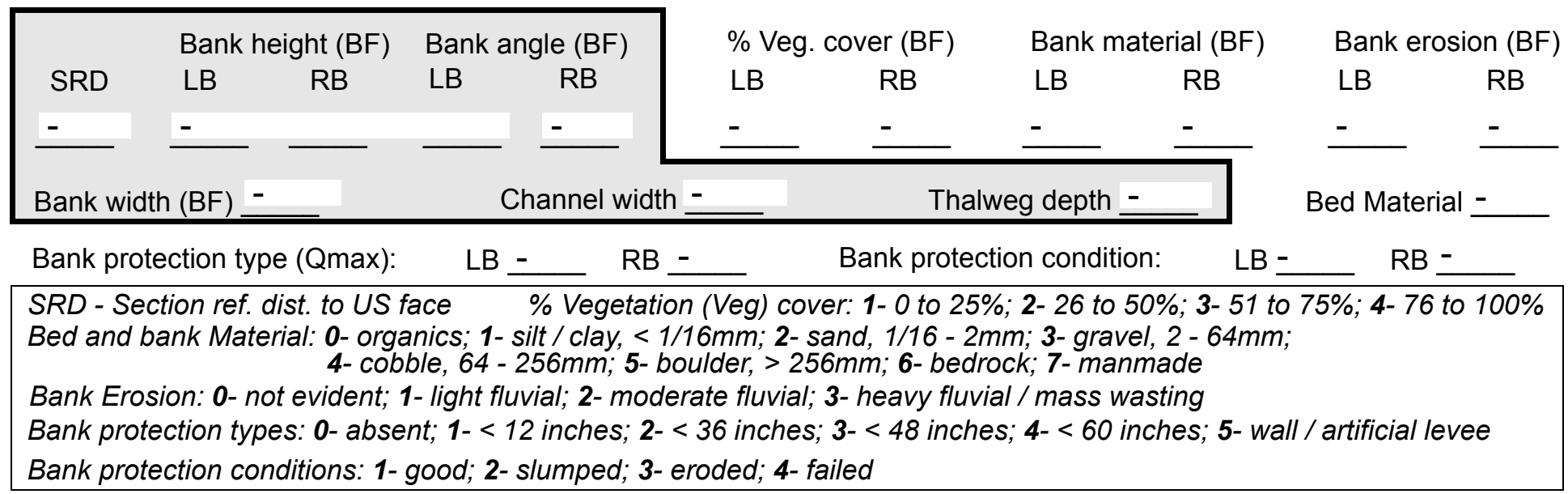

Comments (eg. bank material variation, minor inflows, protection extent, etc.):

-

NO PIERS

101. Is a drop structure present? 2 2 (Y or $N$, if $N$ type ctrl-n ds) 102. Distance: ___ feet 103. Drop: -_ feet 104. Structure material: 2 (1- steel sheet pile; 2- wood pile; 3- concrete; 4- other) 105. Drop structure comments (eg. downstream scour depth):

120

120

1

1

10

$\mathbf{0}$ 
Point bar extent: Ther feet $\underline{\mathbf{e} \text { is }}$ (US, UB, DS) to a feet lay (US, UB, DS) positioned er \%LB to $\underline{\text { of }} \%$ RB Material: thi

Point or side bar comments (Circle Point or Side; note additional bars, material variation, status, etc.):

ck muck on the bed. There is silt/ clay material in the channel bed near the bridge and just DS of the bridge.

Is a cut-bank present?

Cut bank extent: feet (Y or if $N$ type ctrl-n cb) Where? (LB or $R B)$ feet (US, UB, DS)

Bank damage: (US, UB, DS) to (1- eroded and/or creep; 2- slip failure; 3- block failure)

Cut bank comments (eg. additional cut banks, protection condition, etc.):

\section{$\mathbf{N}$}

$-$

$\underline{\text { Is channel scour present? }}$ NO (Y or if N type ctrl-n cs) Mid-scour distance: DRO Scour dimensions: Length $\underline{\mathbf{P}}$ Width $\underline{\text { STR Depth: }} \underline{\mathbf{U C}} \quad$ Positioned $\underline{\text { TU }}$ \%LB to $\underline{\mathbf{R E}}$ \%RB Scour comments (eg. additional scour areas, local scouring process, etc.):

\section{Are there major confluences?} ( $Y$ or if $N$ type ctrl-n $m c)$

Confluence 1: Distance Enters on (LB or $R B)$

Confluence 2: Distance Enters on (LB or $R B)$ Confluence comments (eg. confluence name):
How many? $\underline{\mathbf{N}}$

Type (1- perennial; 2- ephemeral)

Type (1- perennial; 2- ephemeral)

\section{F. Geomorphic Channel Assessment}

107. Stage of reach evolution -

1- Constructed

2- Stable

3- Aggraded

4- Degraded

5- Laterally unstable

6- Vertically and laterally unstable 
108. Evolution comments (Channel evolution not considering bridge effects; See HEC-20, Figure 1 for geomorphic descriptors):

NO POINT BARS

N

$-$

$-$

$-$

$-$

$-$

$-$

NO CUT BANKS 


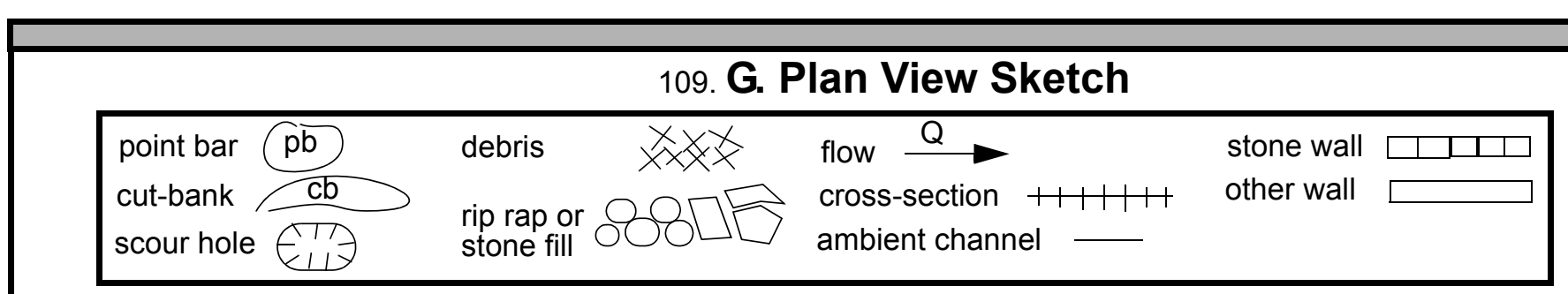


APPENDIX E:

SCOUR COMPUTATIONS 


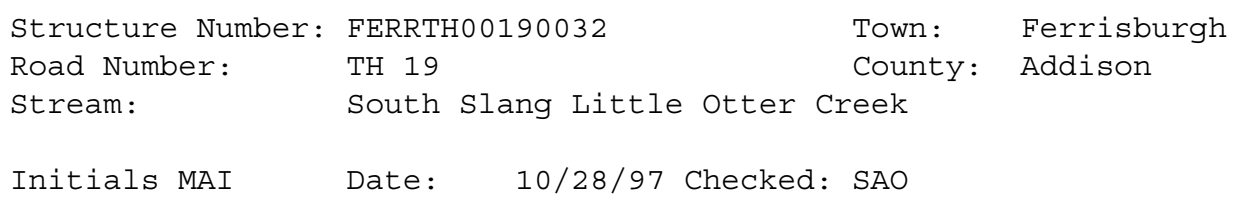




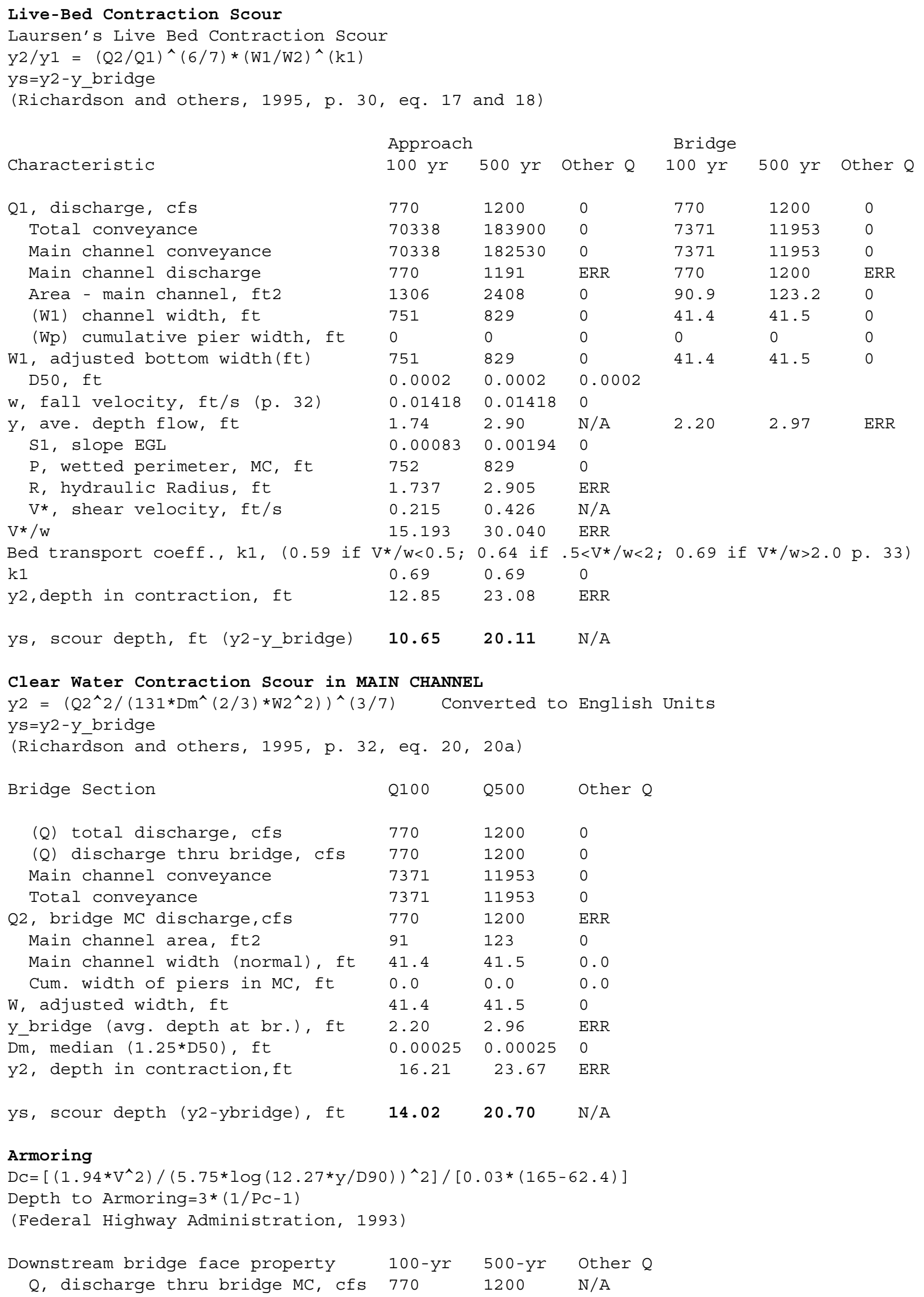

\section{Armoring}

$\mathrm{DC}=\left[\left(1.94 * \mathrm{~V}^{\wedge} 2\right) /(5.75 * \log (12.27 * \mathrm{Y} / \mathrm{D} 90))^{\wedge} 2\right] /[0.03 *(165-62.4)]$

Depth to Armoring $=3 *(1 / \mathrm{PC}-1)$

(Federal Highway Administration, 1993)

Downstream bridge face property 100-yr 500-yr Other $Q$ Q, discharge thru bridge MC, Cfs $770 \quad 1200 \quad$ N/A 


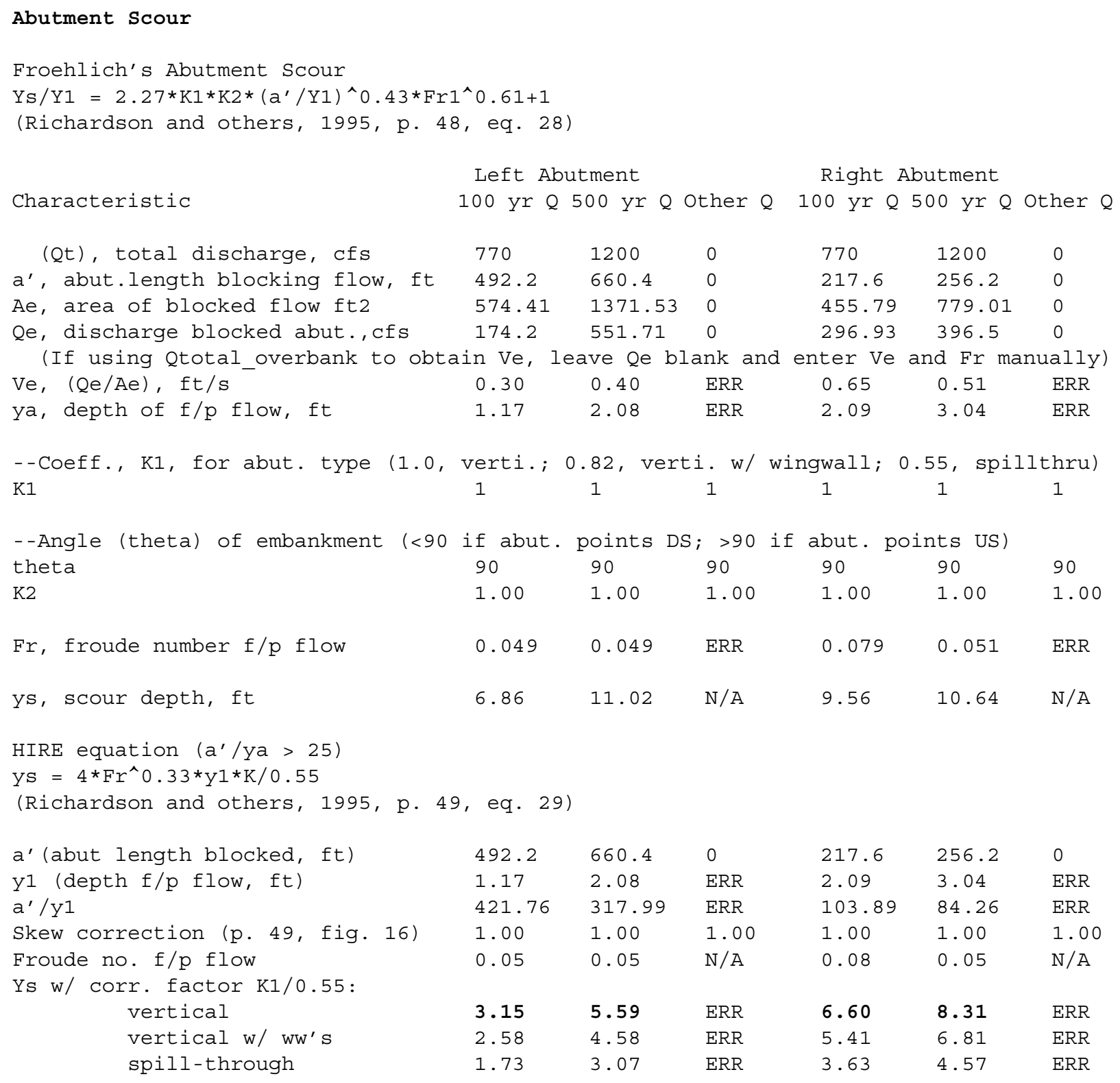

\section{Abutment riprap Sizing}

Isbash Relationship

$\mathrm{D} 50=\mathrm{y} * \mathrm{~K} * \mathrm{Fr}{ }^{\wedge} 2 /(\mathrm{Ss}-1)$ and $\mathrm{D} 50=\mathrm{y}^{\star} \mathrm{K} *\left(\mathrm{Fr}^{\wedge} 2\right)^{\wedge} 0.14 /(\mathrm{Ss}-1)$

(Richardson and others, 1995, p112, eq. 81,82)

\begin{tabular}{|c|c|c|c|c|c|c|}
\hline Characteristic & Q100 & Q500 & Other $Q$ & Q100 & Q500 & Other $Q$ \\
\hline Fr, Froude Number & 1 & 1 & 0 & 1 & 1 & 0 \\
\hline y, depth of flow in bridge, ft & 2.20 & 2.96 & 0.00 & 2.20 & 2.96 & 0.00 \\
\hline Median Stone Diameter for ripra & $t:$ left & butmen & & right & abutment & ft \\
\hline Fr<=0.8 (vertical abut.) & ERR & ERR & 0.00 & ERR & ERR & 0.00 \\
\hline Fr>0.8 (vertical abut.) & 0.92 & 1.24 & ERR & 0.92 & 1.24 & ERR \\
\hline
\end{tabular}


